Article

\title{
Long- and Short-Term Inorganic Nitrogen Runoff from a Karst Catchment in Austria
}

\author{
Thomas Dirnböck ${ }^{1, *} \mathbb{D}$, Heike Brielmann ${ }^{1}$, Ika Djukic ${ }^{1}$, Sarah Geiger ${ }^{1}$, Andreas Hartmann ${ }^{2,3}$, \\ Franko Humer ${ }^{1}$, Johannes Kobler ${ }^{1}$, Martin Kralik ${ }^{1,4}$, Yan Liu ${ }^{2}$, Michael Mirtl ${ }^{1,5}$ and \\ Gisela Pröll ${ }^{1}$ \\ 1 Environment Agency Austria, Spittelauer Lände 5, A-1090 Vienna, Austria; \\ heike.brielmann@umweltbundesamt.at (H.B.); ika.djukic@umweltbundesamt.at (I.D.); \\ sarah.geiger@umweltbundesamt.at (S.G.); franko.humer@umweltbundesamt.at (F.H.); \\ johannes.kobler@umweltbundesamt.at (J.K.); martin.kralik@univie.ac.at (M.K.); \\ michael.mirtl@umweltbundesamt.at (M.M.); gisela.proell@umweltbundesamt.at (G.P.) \\ 2 Chair of Hydrological Modeling and Water Resources, University of Freiburg, 79098 Freiburg, Germany; \\ andreas.hartmann@hydmod.uni-freiburg.de (A.H.); yan.liu@hydmod.uni-freiburg.de (Y.L.) \\ 3 Department of Civil Engineering, University of Bristol, Tyndall Ave, Bristol, England BS8 1UG, UK \\ 4 Department of Environmental Geosciences, University of Vienna, Althanstraße 14, A-1090 Vienna, Austria \\ 5 Helmholtz Centre for Environmental Research GmbH-UFZ, Permoserstraße 15, 04318 Leipzig, Germany \\ * Correspondence: thomas.dirnboeck@umweltbundesamt.at; Tel.: +43-1-313043442
}

Received: 8 September 2020; Accepted: 16 October 2020; Published: 20 October 2020

check for updates

\begin{abstract}
Excess nitrogen $(\mathrm{N})$ deposition and gaseous $\mathrm{N}$ emissions from industrial, domestic, and agricultural sources have led to increased nitrate leaching, the loss of biological diversity, and has affected carbon (C) sequestration in forest ecosystems. Nitrate leaching affects the purity of karst water resources, which contribute around $50 \%$ to Austria's drinking water supply. Here we present an evaluation of the drivers of dissolved inorganic $N$ (DIN) concentrations and fluxes from a karst catchment in the Austrian Alps (LTER Zöbelboden) from 27 years of records. In addition, a hydrological model was used together with climatic scenario data to predict expected future runoff dynamics. The study area was exposed to increasing $\mathrm{N}$ deposition during the 20th century (up to 30 to $35 \mathrm{~kg} \mathrm{~N} \mathrm{ha}^{-1} \mathrm{y}^{-1}$ ), which are still at levels of $25.5 \pm 3.6$ and $19.9 \pm 4.2 \mathrm{~kg} \mathrm{~N} \mathrm{ha}^{-1} \mathrm{y}^{-1}$ in the spruce and the mixed deciduous forests, respectively. Albeit $\mathrm{N}$ deposition was close to or exceeded critical loads for several decades, $70 \%-83 \%$ of the inorganic $\mathrm{N}$ retained in the catchment from 2000 to 2018, and $\mathrm{NO}_{3}{ }^{-}$concentrations in the runoff stayed $<10 \mathrm{mg} \mathrm{L}^{-1}$ unless high-flow events occurred or forest stand-replacing disturbances. We identified tree growth as the main sink for inorganic $\mathrm{N}$, which might together with lower runoff, increase retention of only weakly decreasing $\mathrm{N}$ deposition in the future. However, since recurring forest stand-replacement is predicted in the future as a result of a combination of climatically driven disturbance agents, pulses of elevated nitrate concentrations in the catchment runoff will likely add to groundwater pollution.
\end{abstract}

Keywords: LTER; karst water; nitrogen deposition; nitrogen saturation; nitrate; ammonium; runoff; water quality

\section{Introduction}

Excess nitrogen $(\mathrm{N})$ deposition and gaseous $\mathrm{N}$ emissions from industrial, domestic, and agricultural sources have led to increased nitrate leaching, the loss of biological diversity, and has affected carbon (C) sequestration in forest ecosystems [1-4]. Global mean N deposition is still increasing [5] while in Europe, $\mathrm{N}$ deposition peaked during the mid-1980s and was slowly going down until present day as a result of emission reductions (EU28) of $\mathrm{NO}_{x}$ by $50 \%$ and $\mathrm{NH}_{3}$ by $30 \%$ between the years 1990 
and 2015 [6]. However, the amount of $\mathrm{N}$ deposition did not decrease in all areas in Europe [7] and the currently legislated emission reduction targets are too low to save ecosystems and biodiversity from further effects [8,9]. In order to assess the ecosystem effects of chronically high $\mathrm{N}$ deposition (among other air pollutants) in the forests of the Northern Limestone Alps in Austria, the long-term monitoring station "Zöbelboden" was set up in the year 1992. After 27 years of continuous observation and a number of experimental studies, we provide here an integrated view of these effects. Since half of the Austrian drinking water resources stem from karst areas [10] such as our study catchment, detailed knowledge about the drivers of $\mathrm{N}$ loss in upstream karst areas in the form of the water pollutant nitrate is pivotal. The more so because it may deviate from other catchments owing to a strong heterogeneity of subsurface flow and storage characteristics [11], and shallow, stony soils with low filtering capacity $[12,13]$. Nitrate may therefore additionally pollute downstream water sources already affected by agricultural fertilization $[14,15]$. An oversupply of $\mathrm{N}$ is thought to gradually diminish $\mathrm{N}$ retention in the living biomass and the soil so that surplus $\mathrm{N}$ leaves the ecosystem via leaching or gaseous emissions [16,17]. Cross-catchment studies have however shown that $\mathrm{N}$ retention is high even in areas with considerable $\mathrm{N}$ deposition $[18,19]$, and signs of increasing oligotrophication [20].

$\mathrm{N}$ retention in trees only decreases beyond a certain level of $\mathrm{N}$ deposition while it increases at lower levels [21-23]. Since the deposition of $\mathrm{N}$ is in the range of expected growth reduction in European beech and Norway spruce [22], the dominating tree species at Zöbelboden, we expected such an effect. However, we were not able to single out this effect from the manifold factors of tree growth. Therefore, we explored our data on nutrient concentrations in leaves and needles. The down-regulation of tree growth can be related to nutrient deficiencies as a result of previous $\mathrm{N}$-driven growth enhancement, reduced fine root biomass, and a change in the composition and abundance of mycorrhizal fungi [24,25].

Apart from the retention of deposited $\mathrm{N}$ in plant biomass, substantial amounts end up in the soil [26]. Fertilization experiments in forests show $\mathrm{N}$ addition generally increases soil organic matter (SOM) storage $[27,28]$ but the amount of retained $\mathrm{N}$ depends upon the soil C: $\mathrm{N}$ ratio because microbial immobilization of added $\mathrm{N}$ may be low in soils with a C:N ratio $<20$ [17].

The controlling role of the soil C: $\mathrm{N}$ ratio on $\mathrm{N}$ immobilization is also reflected in its tight relationship with the leaching of dissolved inorganic $N(D I N)$, predominately in the form of nitrate $[29,30]$. The retention of DIN in catchments distributed across unmanaged European forest areas with no local $\mathrm{N}$ emission sources is high but decreased with increasing inorganic $\mathrm{N}$ deposition [18]. Since our catchment has been exposed to chronic $\mathrm{N}$ deposition for at least three decades before the monitoring started, and because DIN leaching seems to react very fast to the addition of DIN [31], we did not expect a long-term trend in DIN export within the timeframe of monitoring. However, apart from the long-term effects of high $\mathrm{N}$ deposition on DIN leaching, short-term disturbances such as forest stand-replacement, either naturally or due to management, can significantly increase nitrate loss with the seepage of water [32-34] thereby elevating the catchment runoff of DIN [35-37]. Knowledge about the interactive effects of long-term chronic $\mathrm{N}$ deposition with stand-replacing disturbances is important [38], because in Europe's forests, disturbances from wind, bark beetle and wildfires have already and are expected to increase further in response to climate change [39,40]. Beginning during the year 2006, storms and spruce bark beetle outbreaks have caused stand replacement in $5 \%-10 \%$ of the study area with an immediate increase in the DIN runoff [37]. Therefore, we expected that forthcoming disturbances will likely lead to pulses of nitrate loss in our study catchment, too.

Based on an analysis of the input-output budget of $\mathrm{N}$, we explored vegetation, soil, and other catchment sinks in order to explain the likely effects of $\mathrm{N}$ deposition on nitrate leaching and to provide an outlook to the future. In detail, we (1) hypothesized increasing deficiency of $\mathrm{P}$ and $\mathrm{K}$ as found in other sites with high $\mathrm{N}$ deposition $[7,22,41]$, and (2) increased soil $\mathrm{N}$ storage $[27,28]$ and decreasing $\mathrm{C}: \mathrm{N}$ ratios [17] in the soils, which we analyzed with long-term soil inventory data supplemented with a plot-scale $\mathrm{N}$ fertilization experiment focusing on SOM decomposition. With climate scenario data, the application of a hydrological model, and the knowledge we have gained through analyzing the 
long-term data from Zöbelboden, we discuss the potential impact of the manifold drivers on nitrate discharge in the future.

\section{Methods}

\subsection{Study Site}

LTER Zöbelboden has a size of 90 ha and is situated in the northern part of the national

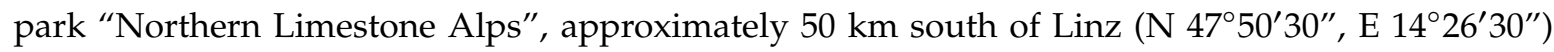
(https://deims.org/8eda49e9-1f4e-4f3e-b58e-e0bb25dc32a6) (Figure 1). The altitude ranges from $550 \mathrm{~m}$ to $956 \mathrm{~m}$ a.s.l. The main rock type is Norian dolomite (Hauptdolomit), which is partly overlain by limestone (Plattenkalk). Due to the dominating dolomite, the watershed is not as heavily karstified as limestone karst systems but shows typical karst features, such as conduits and sinkholes. These conduits and sinkholes provide pathways for rapid water flow and quick response times to water input at the soil-bedrock interface. The long-term average annual temperature is $7.2^{\circ} \mathrm{C}$. The coldest monthly temperature at $900 \mathrm{~m}$ a.s.l. is $-1{ }^{\circ} \mathrm{C}$ in January, the highest is $15.5^{\circ} \mathrm{C}$ in August. Annual rainfall ranges from 1500 to $1800 \mathrm{~mm}$. Monthly precipitation ranges from $75 \mathrm{~mm}$ (February) to $182 \mathrm{~mm}$ (July). Snowfall occurs between October and May with an average duration of snow cover of about 4 months. From the start of the project in 1992 onwards, forest management has been restricted to single tree harvesting just in case of bark beetle infestation. Wind throw is frequent in the area with single tree events and events affecting larger areas.
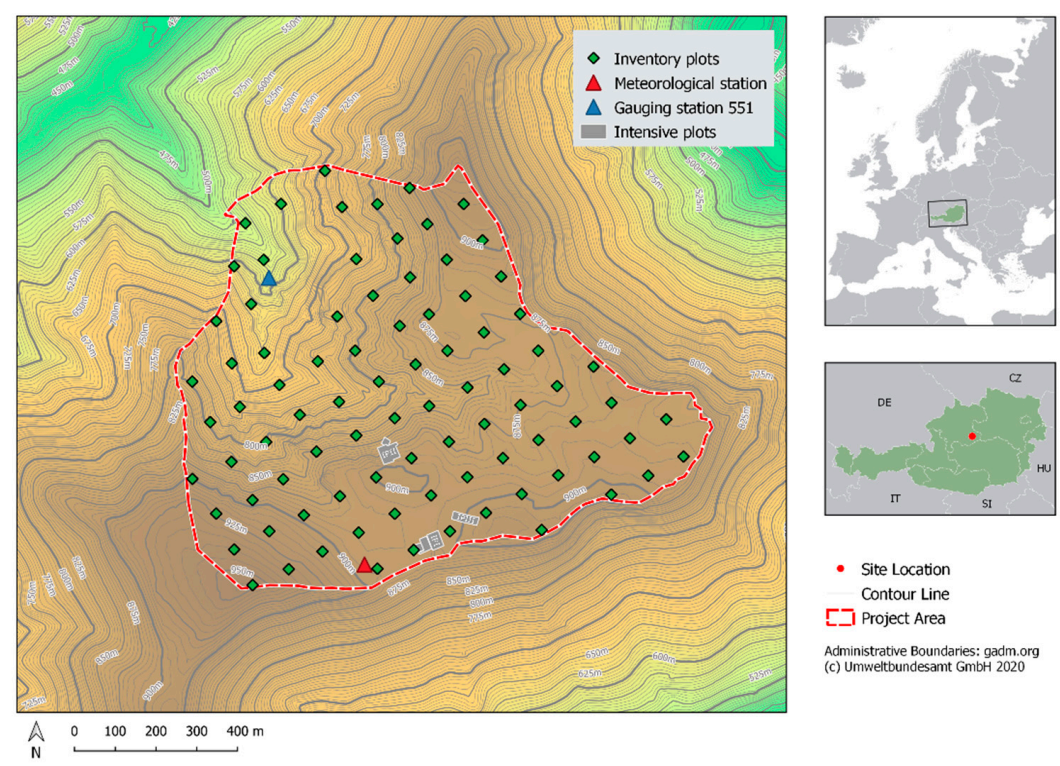

Figure 1. Location of LTER Zöbelboden with the main monitoring installations.

The catchment can be divided into two distinct sites: A very steep $\left(30-70^{\circ}\right)$ slope from $550-850 \mathrm{~m}$ a.s.l. and an almost flat plateau (850-956 $\mathrm{m}$ a.s.l.) on the top of the mountain. The areal coverage of each site is $50 \%$ of the watershed. At each site, one plot has been selected for intensive measurements of hydrochemical variables (Figure 1). Intensive plot I (IP I) is located on the plateau where Chromic Cambisols and Hydromorphic Stagnosols are found. This plot was moved to a nearby location (IP III) in 2008 with the same characteristics because of forest disturbance. Intensive plot II (IP II) is located on the slope and is dominated by Lithic and Rendzic Leptosols (FAO/ISRIC/ISSS, 2006). The mean slopes are $14^{\circ}$ at IP I and $36^{\circ}$ at IP II. IP I is dominated by Norway spruce (Picea abies (L.) H. Karst.) following plantation after a clear cut around the year 1910, whereas a mixed mountain forest with beech (Fagus sylvatica L.) as the dominant species, Norway spruce, sycamore (Acer pseudoplatanus L.), and ash (Fraxinus excelsior L.) covers IP II. 
Wind throw and bark beetle disturbances started in 2006 with the damages caused by the storm Kyrill followed by two other storms in 2008. The subsequent spruce bark beetle outbreak peaked in the year 2011 (Figure 2). At Zöbelboden, these disturbances mostly damaged single trees and groups of trees while stand replacement of larger areas ( $>0.5$ ha) only occurred in $5 \%$ to $10 \%$ of the catchment.

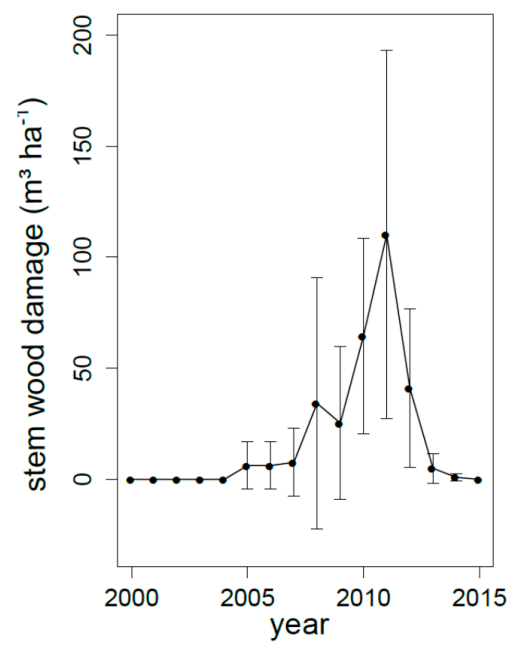

Figure 2. Wind throw and spruce bark beetle disturbance in the Kalkalpen National Park between 2000 and 2015.

\subsection{Climate and Air Pollution}

Meteorological data (air temperature, precipitation, vapor pressure, wind speed, and solar radiation) were recorded half-hourly at two climate stations, at a clearing area at the plateau $(950 \mathrm{~m}$ a.s.l., $280 \mathrm{~m}$ distance to the monitoring plot) and at a nearby tower ( $40 \mathrm{~m}$ height, $60 \mathrm{~m}$ distance to the plot). The tower can be considered to represent the climatic situation at the monitoring plot, therefore data from the clearing area was regressed to the tower, resulting in a daily record from 1993 to 2019. Data gaps were filled with nearby climate stations based on linear regression (all within a radius of $10 \mathrm{~km}$ ). Snow depth was measured weekly with a measuring stick during the sampling campaigns. In order to explore the climatic changes since 1950, long-term temperature and precipitation data from a nearby station (Reichraming, Hydrografischer Dienst) at $360 \mathrm{~m}$ a.s.l was bias-corrected with on-site meteorological data. We used the monthly mean difference between temperature and precipitation in the years 1993 to 2010, when data from both stations were available and adjusted for those of the entire data series of the Reichraming station.

Bulk precipitation was collected at the clearing (non-forested) area adjacent to the climate station with 5 to 10 (from 2005 onwards) bulk collectors, each with $20 \mathrm{~cm}$ in diameter. Water samples were pooled, filtered, and kept cool $\left(4{ }^{\circ} \mathrm{C}\right)$ until sample preparation. Weekly samples were mixed (volume-weighted) biweekly or monthly (from 2008 onwards due to financial reasons). Nitrate was analyzed by ion chromatography with conductivity detection (Dionex IC System 4000 I until 2002, thereafter with Dionex IC System Serie DX 500). Total N was determined by means of spectrophotometric analysis (Abimed TN 05). $\mathrm{NH}_{4}{ }^{+}$concentrations of the weekly samples were also measured by spectrophotometry (Milton Roy Spectronic).

We calculated the total deposition of $\mathrm{N}$ for the two intensively measured sites as the sum of throughfall and canopy exchange. The latter was based on a canopy exchange model according to Staelens et al. [42] with sodium as the tracer ion, bulk precipitation and throughfall, a yearly time step, and relative uptake efficiency of $\mathrm{NH}_{4}{ }^{+}$of 6 . In order to get a long-term deposition of $\mathrm{N}$, we scaled reconstructed deposition from 1880 to 2000 [43] to the measurements using the mean bias during the years when both were available as a correction factor. Throughfall was collected at each intensively measured site with 15 regularly distributed bulk deposition samplers $(\emptyset=20 \mathrm{~cm})$. From 2006-2008, 
an additional two to five deposition samplers collected throughfall in the small bark beetle gap at IPI. While throughfall measurements ceased at IPI in September 2009 due to small-scale wind throw events and bark beetle infestations, measurements started at IPIII in August 2008. For chemical analyses, throughfall samples were pooled for each individual monitoring plot, except for bark beetle gap samples at IPI, which comprised individual samples. Subsequent throughfall sample preparation and analyses correspond to the described method for bulk precipitation.

\subsection{Foliage Nutrient Concentrations}

The dominant tree species, Norway spruce and European beech were sampled from a subsample of the forest and soil inventory plots distributed in a $100 \times 100 \mathrm{~m}$ grid covering the entire study area (90 ha) and from the intensively monitored plots at the plateau (IP I and IP III) and the slope (IP II). Sampling began in the year 1992 for spruce needles and in 1993 for beech leaves. Between 36 and 52 dominant or predominant spruce trees and 16 to 17 beech trees were sampled annually until 2003. Thereafter sampling took place in the years 2004 (subsample of spruce trees), 2006, 2008, 2011, 2014, and 2017. In 2015, 2016, 2018, and 2019, only leaves and needles of the trees at IP I and IP III were collected and analyzed. All sample trees of the inventory plots were located as close as possible but outside the 10 (8) $\mathrm{m}$ circle of the forest inventory and the $100 \mathrm{~m}^{2}$ vegetation plot. We chose new sample trees as close as possible to prior ones in case of damage or decreasing vitality. During each sampling campaign, we collected a 41 plastic bag of mature leaves from the upper third of the north-west exposed crown of each beech tree. From spruce trees, the current and one-year-old needles were collected separately in a $0.5 \mathrm{~L}$ bag from as close as possible to the 7 th whirl (counted from the top) of the north-west exposed crown. In some years until 2003, leaves and needles were collected separately from all four cardinal directions. Sampling took place in late August and September and in late September and October, respectively for beech and spruce. All specimen were labeled and then stored at $<4{ }^{\circ} \mathrm{C}$ until pretreatment and analysis in the lab.

The specimens were oven-dried $\left(30^{\circ} \mathrm{C}\right)$ until constant weight, separated from the twigs, and grounded with an ultra-centrifugal grinding mill (ZM1, Retsch, D). Dry mass at $105{ }^{\circ} \mathrm{C}$ was determined with a subsample of 100 undamaged spruce needles. Another subsample was digested $\left(\mathrm{HNO}_{3} / \mathrm{HClO}_{4}\right)$ in glass vessels on a heating block (SMA $20 \mathrm{~A}$, Gerhardt, D) to measure total residue with gravimetric vapor sorption at $105^{\circ} \mathrm{C}$. Subsequent determination of $\mathrm{Ca}, \mathrm{K}, \mathrm{Mg}, \mathrm{Mn}$, and total $\mathrm{P}$ was carried out with inductively coupled plasma optical emission spectrometry (ICP-OES; Perkin-Elmer Optima 3000 XL, 3000 DV, and 7300 DV). Total N was measured by means of potentiometric titration (Kjeldatherm Vapotest 4S Gerhardt).

Foliage deficiency thresholds were taken from Mellert and Göttlein [44]. Temporal trends of single nutrients and ratios (N:Ca, N:Mg, N:K, and N:P) were tested using a Wilcoxon rank-sum test after outlier deletion comparing the first 4 years with the last 4 years (boxplot function).

\subsection{Soil Chemistry}

We collected mixed soil samples at 64 plots between July and August 2014 to compare with the soil survey data of the years 1992 and 2004. These plots were $100 \mathrm{~m}$ apart covering the entire catchment. For one mixed soil sample, three individual soil cores with $4 \mathrm{~cm}$ diameter were taken from the upper mineral soil layer $(0-10 \mathrm{~cm})$ after litter removal. The soil cores were taken with a $2.5 \mathrm{~m}$ distance to the 1992 and 2004 sampling sites. In 2004, the samples were taken $5 \mathrm{~m}$ apart from the samples in 1992. In all surveys, soil samples were dried at approximately $30^{\circ} \mathrm{C}$, coarse aggregates crushed and dried again until constant weight. Then they were sieved through a $2 \mathrm{~mm}$ sieve. Soil suspensions were made by dissolving $5 \mathrm{~g}$ of each soil sample in $12.5 \mathrm{~mL}$ of $0.01 \mathrm{M} \mathrm{CaCl}_{2}$ solution and $\mathrm{pH}$ was measured electrochemically with a pH electrode (Metrohm 654 pH meter in 1992 and 2004 and Argus $\mathrm{X} \mathrm{pH}$ meter in 2014). For the determination of the C:N-ratio, the soil samples were ground and further decarbonized using $3 \mathrm{M} \mathrm{HCl}$ solution. The organic carbon content was measured after dry combustion using isotope-ratio mass spectroscopy (IRMS). These methods deviate from the analysis 
in 1992 and 2004 where the total content of organic C (TOC) was calculated by subtracting the total content of $\mathrm{CaCO}_{3}$ from the total content of $\mathrm{C}$ (TC-TIC). The total content of C (TC) was analyzed by dry combustion $\left(1300^{\circ} \mathrm{C}\right)$. Released $\mathrm{CO}_{2}$ was detected coulometrically (Ströhlein Coulomat 702 and $\mathrm{Si}$ 111/6). The total content of $\mathrm{CaCO}_{3}$ (TIC) was measured via the addition of $\mathrm{HCl}$ and volumetrically determination of the released $\mathrm{CO}_{2}$ (Scheibler). The total content of $\mathrm{N}$ of the year's samples was determined by a modified Kjeldahl method. The organic $\mathrm{N}$ was converted to $\mathrm{NH}_{4}{ }^{+}$by digestion with $\mathrm{H}_{2} \mathrm{SO}_{4}$ and a catalyst (Kjeldahlterm KT8 Gerhardt). The accumulated $\mathrm{NH}_{4}{ }^{+}$was converted to $\mathrm{NH}_{3}$ (distillation) and measured by potentiometric titration. To account for $\mathrm{N}$ oxygen compounds, salicylic acid was added prior to digestion. For the determination of total $\mathrm{N}$ stocks, the forest floor was sampled once with a $30 \times 30 \mathrm{~cm}$ frame and the mineral soil with a metal pole with a $70 \mathrm{~mm}$ diameter at 3 points within a distance of two meters. Differences between years were tested using a paired Wilcoxon test.

\subsection{Catchment Hydrology and N Measurements}

Artificial tracer experiments, carried out in our study area, showed the large heterogeneity of the hydrologic system ranging from the retardation of 1 day to 10 years [45]. Water age dating with CFCs, ${ }^{3} \mathrm{H}$, and ${ }^{3} \mathrm{H} /{ }^{3} \mathrm{He}$ even showed mean residence times of up to 20 years at one spring. Estimating the water balance of the larger system demonstrated that major parts of the rainfall input are transformed into the intermediate flow and deep percolation within the dolomite leaving the system as diffuse runoff instead of surface runoff (Humer and Kralik 2008). For this study, our main source of information was the gauging station (number 551) discharge and N concentration data between 2000 and 2018. Damped $\delta^{18} \mathrm{O}$ variations at this spring indicated a delayed flow component, both fast and slow flow paths, and a considerable fraction of intermediate flow [46]. We disregarded the discharge data before and after this period because we deemed this data too uncertain. The discharge was calculated based on the gauging station's rating curve and 15 min water level sensor data. Missing values were gap-filled based on regression with nearby gauging station data. The recharge area of this spring was estimated based on a model calibration described in detail in [37,46,47].

Weekly observations of $\mathrm{NO}_{3}{ }^{-}-\mathrm{N}, \mathrm{NH}_{4}{ }^{+}-\mathrm{N}$, and total $\mathrm{N}$ were available at the gauging station 551. From 2010 onwards, samples (ISO 5677-6) were filtered $(0.45 \mu \mathrm{m})$ before the analysis. $\mathrm{NH}_{4}{ }^{+}$ concentrations were measured by spectrophotometry (Milton Roy Spectronic). Weekly $\mathrm{NO}_{3}{ }^{-}$and total $\mathrm{N}$ samples were pooled to provide volume-weighted biweekly (until March 2009) and monthly (thereafter) samples. $\mathrm{NO}_{3}{ }^{-}$concentrations were determined by ion chromatography with conductivity detection. DIN input was then calculated as the sum of $\mathrm{NO}_{3}{ }^{-}-\mathrm{N}$ and $\mathrm{NH}_{4}{ }^{+}-\mathrm{N}$. Dissolved organic nitrogen (DON) was calculated as the difference between total $\mathrm{N}$ and DIN. In order to calculate DIN discharge, we filled all missing 15 minutes values with the last weekly measurement value.

In 2018 and 2019, a spectral sensor probe (S:CAN spectro::lyser) with a UV-Vis 220-720 nm detector (15 mm path length) was installed in the measuring weir to obtain 15 minutes $\mathrm{NO}_{3}{ }^{-}$measurements.

\subsection{Hydrochemical Modelling}

We use the VarKarst model [47] for the discharge simulations, which was already performed satisfactorily in a previous study at this site [37]. The VarKarst model considers the variability of a karstic system reflected in the variability of (i) soil and epikarst depths, (ii) concentrated and diffuse recharge to the groundwater storage, and (iii) the epikarst and groundwater hydrodynamics. Spatial heterogeneity is accounted for by a set of $\mathrm{N}$ model compartments, which represent varying system properties over space. The influence of karst conduits is included by simulating concentrated recharge and fast conduit groundwater discharge. The VarKarst model is primarily running on a daily resolution. Details of the model can be found in $[47,48]$.

For discharge projections, we perform the model simulations with the calibrated model parameters at this same site from the previous study [37] using different climate projections. 
We used eight RCP 8.5 scenarios of bias-adjusted regional climate model (RCM) data from the EURO-CORDEX initiative (Table 1), the European branch of the Coordinated Regional Downscaling Experiment (CORDEX) project [49,50], available through the data nodes of the Earth System Grid Federation (ESGF) model data dissemination system [51]. RCP 8.5 assumes emissions to rise throughout the 21st century. Because the actual altitude of a site did not match with the altitude of the closest RCM grid element, the $2 \mathrm{~m}$ air temperature was height corrected using a hypsometric lapse rate of $0.65 \mathrm{~K}$ per $100 \mathrm{~m}$ before temporal averaging was done.

Table 1. Description of the eight regional climate models that are used for the projections of the hydrological modeling.

\begin{tabular}{ccc}
\hline RCM Model & Institute & Resolution \\
\hline CLMcom-CCLM4-8-17 & CNRM-CERFACS-CNRM-CM5 & \\
SMHI-RCA4 & CNRM-CERFACS-CNRM-CM5 & \\
KNMI-RACMO22E & ICHEC-EC-EARTH & \multirow{2}{1}{$12 \mathrm{~km}$, daily } \\
IPSL-INERIS-WRF331F & IPSL-IPSL-CM5A-MR & \\
CLMcom-CCLM4-8-17 & MPI-M-MPI-ESM-LR & \\
MPI-CSC-REMO2009 & MPI-M-MPI-ESM-LR & \\
SMHI-RCA4 & MPI-M-MPI-ESM-LR & \\
DMI-HIRHAM5 & NCC-NorESM1-M & \\
\hline
\end{tabular}

Note: Details of the eight regional climate models (RCMs) under the RCP 8.5 can be found via https://b2share.eudat. eu/records/954510207378405aa897ec3b9f1f0c58.

\section{Results}

\subsection{Climate and Deposition Trends}

While precipitation remained stable since 1950, the temperature increased. The annual mean temperature was $6.56{ }^{\circ} \mathrm{C}$ between 1951 and 1970 and increased by $1.43^{\circ} \mathrm{C}$ to $7.99{ }^{\circ} \mathrm{C}$ in the period 1991 to 2019. The warming started in the late 1980s (Figure 3).

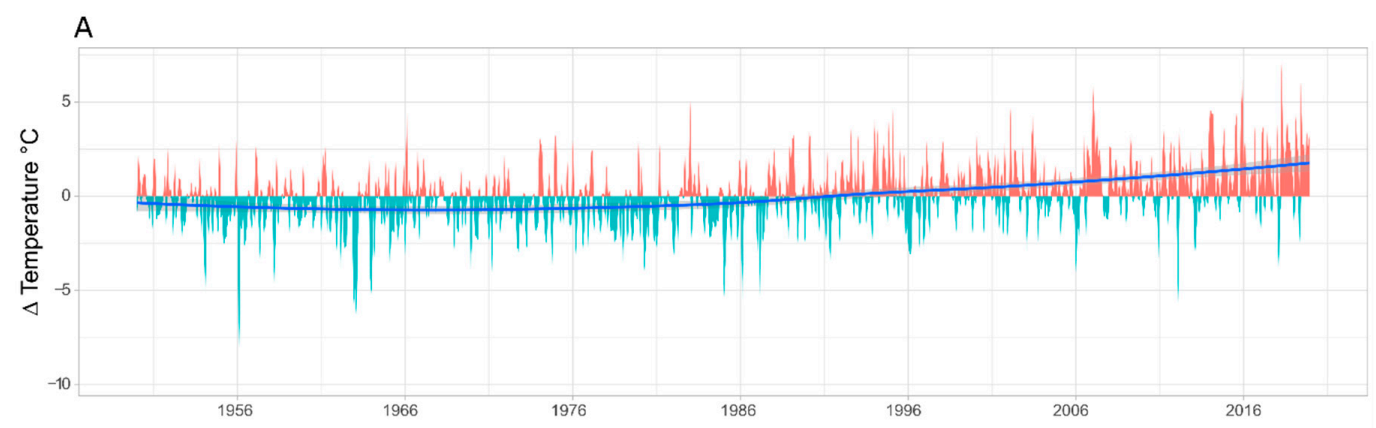

B

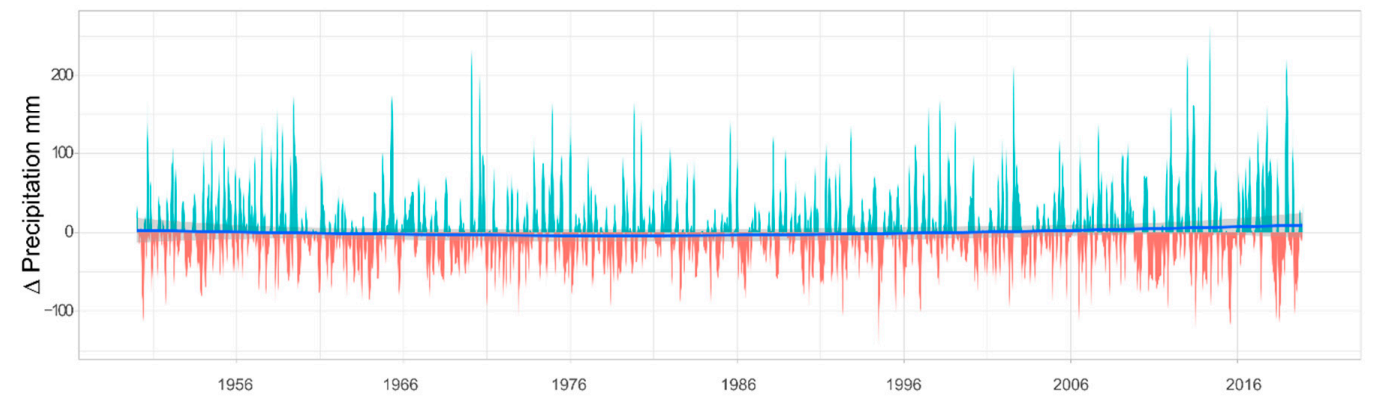

Figure 3. Reconstructed monthly anomalies of (A) temperature and (B) precipitation relative to the years 1961 to 1990 at LTER Zöbelboden. The blue solid lines represent the long-term trend and their confidence interval using a loess smoother. 
The total annual inorganic $N$ deposition between 2000 and 2018 was $25.5 \pm 3.6$ (s.d.) and $19.9 \pm$ $4.2 \mathrm{~kg} \mathrm{~N} \mathrm{ha}^{-1} \mathrm{y}^{-1}$ in the spruce and the mixed deciduous forests, respectively. Two-thirds of the total inorganic $\mathrm{N}$ deposition was in the form of reduced $\mathrm{N}$. The share of dry deposition was higher in the mixed deciduous forests ( $57 \%$ for reduced $\mathrm{N}$ and $15 \%$ for oxidized $\mathrm{N})$ than the spruce forests $(44 \%$ for reduced $\mathrm{N}$ and $10 \%$ for oxidized $\mathrm{N}$ ) (Figure $4 \mathrm{~B}$ ). The annual deposition of DON was $4.8 \pm 1.7$ and $2.5 \pm$ $1.1 \mathrm{~kg} \mathrm{~N} \mathrm{ha}^{-1} \mathrm{y}^{-1}$ in the spruce and the mixed deciduous forests, respectively.
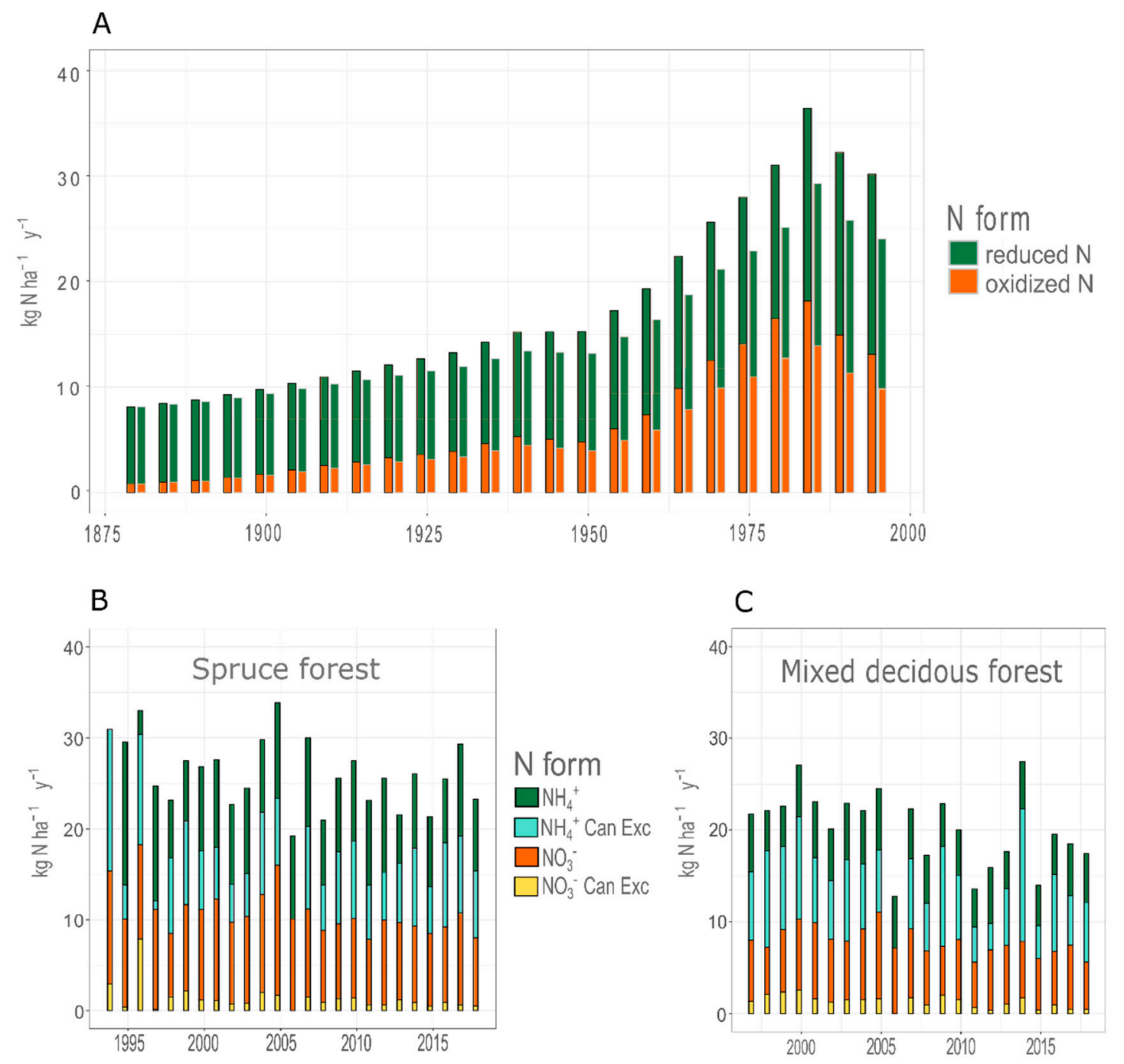

Figure 4. Inorganic $\mathrm{N}$ deposition in the study area. (A) reconstructed deposition between 1880 and 1990 and measured total $\mathrm{NH}_{4}{ }^{+}-\mathrm{N}$ and $\mathrm{NO}_{3}{ }^{-}-\mathrm{N}$ deposition in the two main forest ecosystems in the catchment: (B) spruce dominated forests, and (C) mixed deciduous forests. The pairs in A represent spruce dominated (left) and mixed deciduous forests (right). No shades in B and C indicate missing values.

Based on a reconstruction, total inorganic $\mathrm{N}$ deposition before 1900 was below $10 \mathrm{~kg} \mathrm{~N} \mathrm{ha}^{-1} \mathrm{y}^{-1}$ in the study area. Annual $\mathrm{N}$ deposition peaked in 1980 to approx. 30 to $35 \mathrm{~kg} \mathrm{~N} \mathrm{ha}^{-1} \mathrm{y}^{-1}$ and thereafter only slowly decreased to the current levels (Figure $4 \mathrm{~A}$ ).

\subsection{Foliage Nutrient Concentrations}

N concentration in beech foliage and spruce needles are given in Table 2. Between 1993 and 2018, the $\mathrm{N}$ concentrations decreased significantly $(p>0.05)$ in spruce (current and the one-year-old needles) 
but not in beech. Similarly, foliage concentration of $\mathrm{P}$ decreased in spruce (only one-year-old needles, $p=0.024)$, but not in beech. The beech foliar $\mathrm{N}: \mathrm{K}$ ratio decreased significantly $(p=0.07)$ and the N:Ca ratio increased marginally $(p=0.051)$. In one-year-old spruce needles, the $\mathrm{N}: \mathrm{Mg}$ ratio decreased $(p=0.091)$, and the $\mathrm{N}: \mathrm{Ca}$ increased $(p=0.028)$. For all other nutrients and nutrient ratios, trends were not detected.

Table 2. Mean \pm SE of tree foliage concentrations in Norway spruce and European beech at Zöbelboden (years 1992 to 2019). Nutrient deficiency or surplus according to [44] is given as red $=$ deficient, green = normal, blue $=$ surplus, and critical nutrient ratio levels as red $=$ below limit, green $=$ within limits, blue $=$ above limit.

\begin{tabular}{cccc}
\hline \multirow{2}{*}{$\mathbf{g ~ k g}^{-\mathbf{1}}$} & \multicolumn{2}{c}{ Spruce } & \multirow{2}{*}{ Beech } \\
\cline { 2 - 3 } & Current Year Needles & One-Year Needles & \\
\hline $\mathrm{N}$ & $12.0 \pm 0.08$ & $11.4 \pm 0.08$ & $20.5 \pm 0.13$ \\
\hline $\mathrm{P}$ & $1.1 \pm 0.01$ & $0.8 \pm 0.01$ & $0.7 \pm 0.01$ \\
\hline $\mathrm{K}$ & $4.3 \pm 0.08$ & $3.4 \pm 0.06$ & $6.1 \pm 0.1$ \\
\hline $\mathrm{Ca}$ & $5.1 \pm 0.1$ & $7.6 \pm 0.14$ & $12.8 \pm 0.22$ \\
\hline $\mathrm{Mg}$ & $2.0 \pm 0.03$ & $2.2 \pm 0.03$ & $2.7 \pm 0.5$ \\
\hline $\mathrm{N}: \mathrm{P}$ & $11.3 \pm 0.11$ & $13.8 \pm 0.14$ & $29.0 \pm 0.41$ \\
\hline $\mathrm{N}: \mathrm{K}$ & $3.1 \pm 0.07$ & $3.5 \pm 0.07$ & $3.5 \pm 0.06$ \\
\hline $\mathrm{N}: \mathrm{Ca}$ & $2.5 \pm 0.05$ & $1.6 \pm 0.03$ & $1.7 \pm 0.03$ \\
\hline $\mathrm{N}: \mathrm{Mg}$ & $4.6 \pm 0.09$ & $5.6 \pm 0.1$ & $7.8 \pm 0.14$ \\
\hline
\end{tabular}

\subsection{Soil $N, C$, and C:N Ratio}

Between 1992 to 2014, the mineral soil $(0-10 \mathrm{~cm})$ showed a long-term decrease in the total $\mathrm{N}$ content by $9 \%$ and in the organic C content by $2.5 \%$. Accordingly, the $\mathrm{C}: \mathrm{N}$ ratio decreased, but only after 2004 from 16 to 13.7 (Table 3).

Table 3. Soil total $\mathrm{N}$ and organic $\mathrm{C}$ content, the C:N ratio, and soil $\mathrm{N}$ stocks from resurveys of soil inventories in the years 1992, 2004, and 2014. Statistical significance is indicated with ${ }^{* * *} p<0.001$; ** $p<0.005 ;{ }^{*} p<0.05$.

\begin{tabular}{|c|c|c|c|c|c|}
\hline & 1992 & 2004 & 2014 & $\Delta 1992$ to 2004 & $\Delta 1992$ to 2014 \\
\hline & \multicolumn{5}{|c|}{ Mean \pm SE concentrations $[\%]$ and $C: N$ ratio in the mineral soil $(0-10 \mathrm{~cm})$} \\
\hline Total N & $0.71 \pm 0.04$ & $0.62 \pm 0.04$ & $0.60 \pm 0.03$ & $\downarrow 0.11 * *$ & $\downarrow 0.9 * * *$ \\
\hline Organic C & $10.44 \pm 0.57$ & $9.83 \pm 0.55$ & $7.98 \pm 0.46$ & $\downarrow 0.61$ & $\downarrow 2.46 * * *$ \\
\hline \multirow[t]{2}{*}{$\mathrm{C}: \mathrm{N}$ ratio } & $15.4 \pm 0.5$ & $16 \pm 0.2$ & $13.7 \pm 0.5$ & $\uparrow 0.6$ & $\downarrow 1.6 *$ \\
\hline & \multicolumn{5}{|c|}{ Stocks [kg ha ${ }^{-1}$ ] of total N (median and median absolute deviation) } \\
\hline $\begin{array}{l}\text { Organic } \\
\text { layer }\end{array}$ & $113(79)$ & $255(151)$ & - & $\uparrow 142.4 * * *$ & - \\
\hline $\begin{array}{l}\text { Mineral } \\
\text { layer 0-5 }\end{array}$ & $1644(624)$ & $1430(433)$ & - & $\downarrow 214.6$ ** & - \\
\hline $\begin{array}{c}\text { Mineral } \\
\text { layer 5-10 }\end{array}$ & 1851 (747) & 1599 (484) & - & $\downarrow 251.4 * *$ & - \\
\hline $\begin{array}{c}\text { Mineral } \\
\text { layer 10-20 }\end{array}$ & 2414 (2197) & 1918 (1074) & - & $\downarrow 496.1$ & - \\
\hline
\end{tabular}

Total soil N stocks significantly increased from the year 1992 to 2004 in the organic layer and decreased in the mineral soil layers from 0-10 cm (Table 3). 


\subsection{Long Term Changes in N Discharge}

The average runoff at the main gauging station was $7.24 \pm 51.78$ (SD) $\mathrm{L} \mathrm{s}^{-1}$ totaling to a mean annual catchment runoff of $269 \pm 96 \mathrm{~mm}$ with a maximum in the year 2009 (305 $\mathrm{mm}$ ) and a minimum in the year 2015 (79 mm) (Figure 5A).
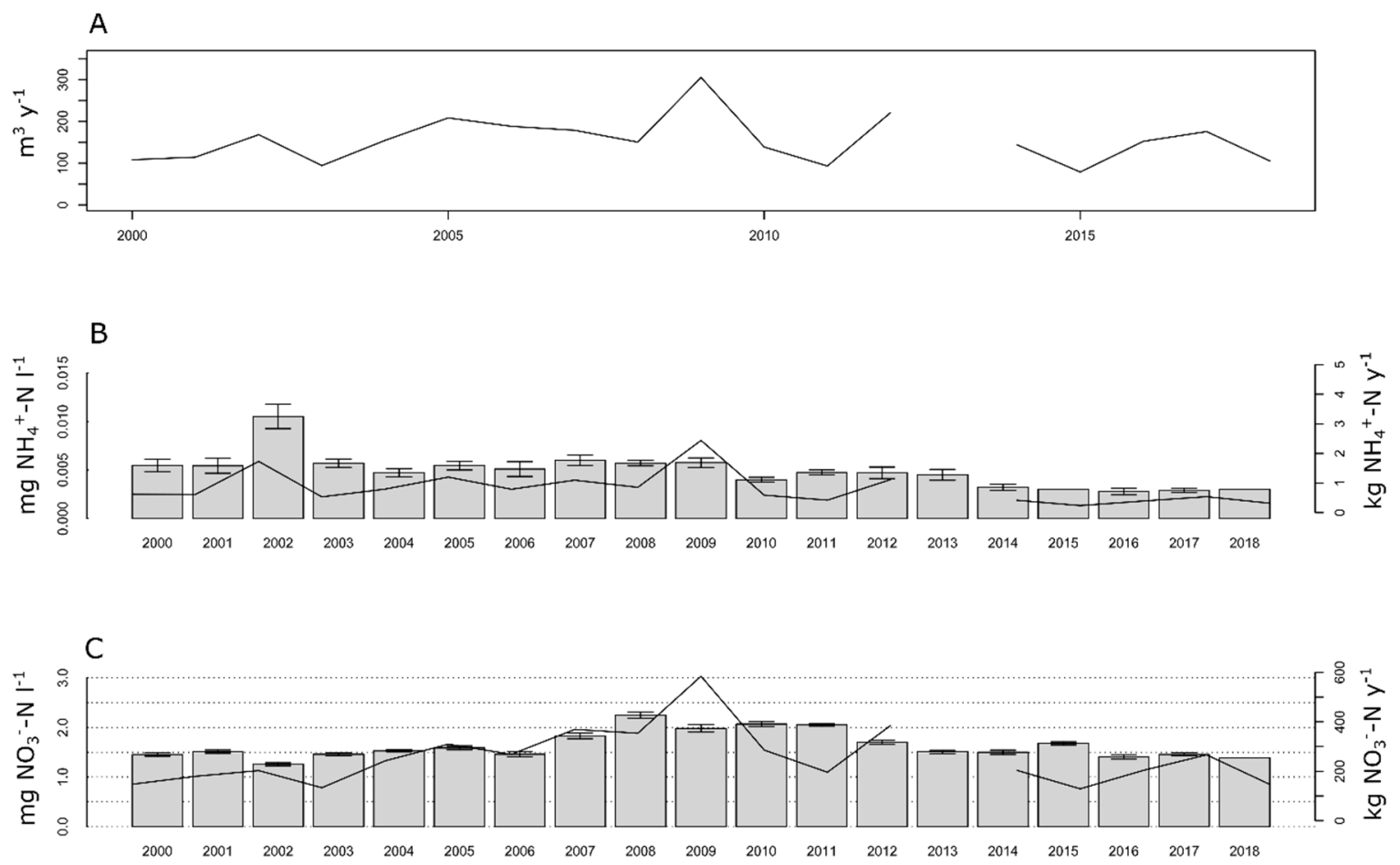

Figure 5. (A) Annual discharge, (B) $\mathrm{NH}_{4}{ }^{+}-\mathrm{N}$ and (C) $\mathrm{NO}_{3}{ }^{-}-\mathrm{N}$ concentrations, and runoff at the gauging station 551 (bars: concentrations in mean $\pm \mathrm{SE}$, lines: fluxes).

The mean annual $\mathrm{NH}_{4}{ }^{+}-\mathrm{N}$ concentrations were $0.005 \pm 0.002 \mathrm{mg} \mathrm{L}^{-1}$ with the highest values in 2002 ( $\left.0.011 \mathrm{mg} \mathrm{L}^{-1}\right)$ and the lowest in the last years from 2015 to $2018\left(0.003 \mathrm{mg} \mathrm{L}^{-1}\right)$. These concentrations total to an annual $\mathrm{NH}_{4}{ }^{+}-\mathrm{N}$ runoff of $0.8 \pm 0.6 \mathrm{~kg}$ at the gauging station (Figure $5 \mathrm{~B}$ ). The annual discharge of $\mathrm{NH}_{4}{ }^{+}-\mathrm{N}$ from the catchment was $0.014 \pm 0.91 \mathrm{~kg} \mathrm{ha}^{-1} \mathrm{y}^{-1}$.

The mean annual $\mathrm{NO}_{3}{ }^{-}-\mathrm{N}$ concentrations were $1.63 \pm 0.27 \mathrm{mg} \mathrm{L}^{-1}$. The highest annual mean occurred in the year $2008\left(2.25 \mathrm{mg} \mathrm{L}^{-1}\right)$, the lowest in the year $2002\left(1.26 \mathrm{mg} \mathrm{L}^{-1}\right)$. These concentrations total to an annual $\mathrm{NO}_{3}{ }^{-}-\mathrm{N}$ runoff of $256 \pm 115 \mathrm{~kg}$ at the gauging station (Figure $5 \mathrm{C}$ ). The annual discharge of $\mathrm{NO}_{3}{ }^{-}-\mathrm{N}$ from the catchment was $4.4 \pm 2 \mathrm{~kg} \mathrm{ha}^{-1} \mathrm{y}^{-1}$. As were the $\mathrm{NO}_{3}{ }^{-}-\mathrm{N}$ concentrations, nitrate runoff peaked in the years of the forest disturbances (2007-2012).

Mean annual DON concentrations were $0.13 \pm 0.07 \mathrm{mg} \mathrm{L}^{-1}$ and annual discharge was $0.33 \pm$ $0.21 \mathrm{~kg} \mathrm{ha}^{-1} \mathrm{y}^{-1}$.

During the upper quartile of discharge at the gauging station, $74 \%$ of the total annual DIN is leaving the catchment via runoff and $50 \%$ of the annual DIN during the highest $10 \%$ runoff events. For DON, these shares are $75 \%$ and $45 \%$, respectively.

During a high-resolution automatic sampling approach in the year 2012, the following rain event-driven dynamics in $\mathrm{NO}_{3}{ }^{-}$at the gauging station could be seen (Figure $6 \mathrm{~A}$ ). Immediately after the start of the first rain event, with $9.6 \mathrm{~mm}$ precipitation, we recorded a decrease in $\mathrm{NO}_{3}{ }^{-}$concentration (Figure 6B). Once the water has passed the soil passage and reached the weir (after 12:00 o'clock on August 24), a small recovery has been noted. During the next stronger event (only two days later) with $19.4 \mathrm{~mm}$ precipitation, we measured an immediate dilution of $\mathrm{NO}_{3}{ }^{-}$caused by surface flow with subsequently a much stronger discharge of $\mathrm{NO}_{3}{ }^{-}$, which had passed soil and the karst 
aquifer. This process shows similar retention behavior as $\delta{ }^{18} \mathrm{O}$ (Figure 6C). These characteristics differ in different springs of our karst catchment showing either no dilution effects or deviating storing capacities.

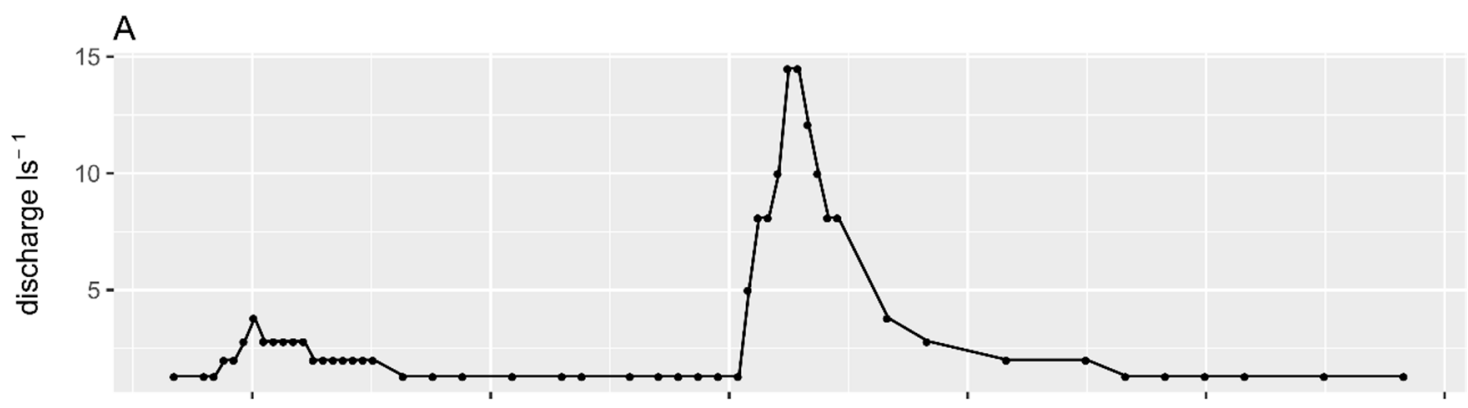

B
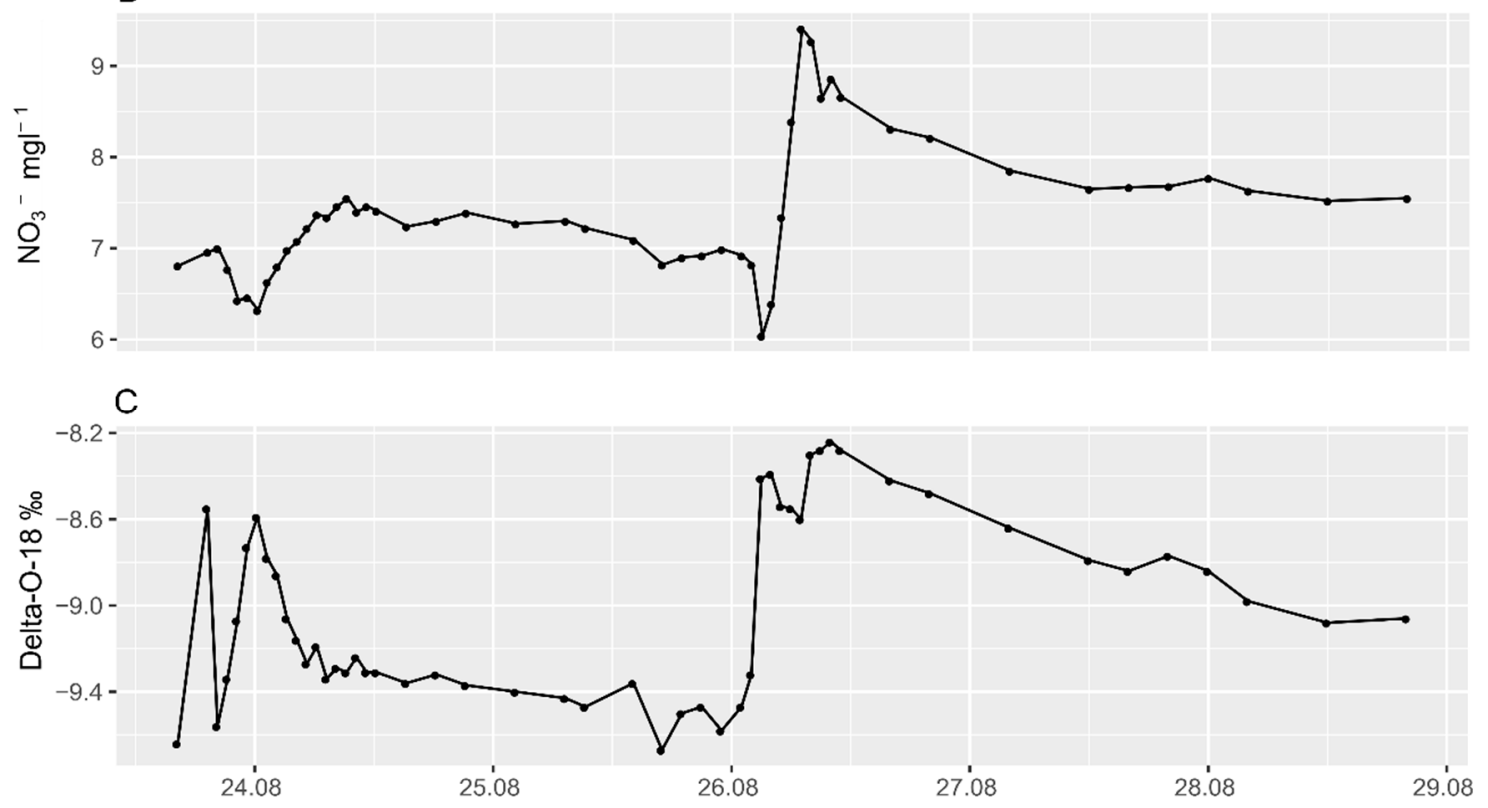

Figure 6. (A) Discharge, (B) $\mathrm{NO}_{3}{ }^{-}$concentrations, and $(\mathbf{C}) \delta^{18} \mathrm{O}$ at the gauging station 551 during a rainfall event in the year 2012 .

When using high-resolution data from the optical probe over an entire year, the $\mathrm{NO}_{3}{ }^{-}-\mathrm{N}$ discharge of the year 2018 was in the range of the grab-sample data (high-resolution data: $2.61 \mathrm{~kg} \mathrm{ha}^{-1} \mathrm{y}^{-1}$; weekly data: $2.55 \mathrm{~kg} \mathrm{ha}^{-1} \mathrm{y}^{-1}$ ).

\subsection{Future Projections of Climate and Discharge}

From the climate projections under RCP 8.5, we see a general decrease in the monthly mean precipitation of the 8 climate models (Figure 7c). The projected monthly mean temperature rises particularly in 2060-2100 (Figure 7d3,d4). Compared to the historical mean monthly discharge, we see a general decreasing trend in the projections (Figure 7a). In the coming 40 years, the change of mean monthly discharge is not substantial (Figure 7a1,a2), whereas the model simulates a large decrease of discharge by the end of this century (Figure 7a4), especially for the high flow period in April and May. For actual evapotranspiration (Figure $7 \mathrm{~b}$ ), the model projects an increase in winter and spring seasons in the last 40 years of this century (Figure $7 \mathrm{~b} 3, \mathrm{~b} 4$ ), but a smaller AET in summer probably due to less available precipitation. 


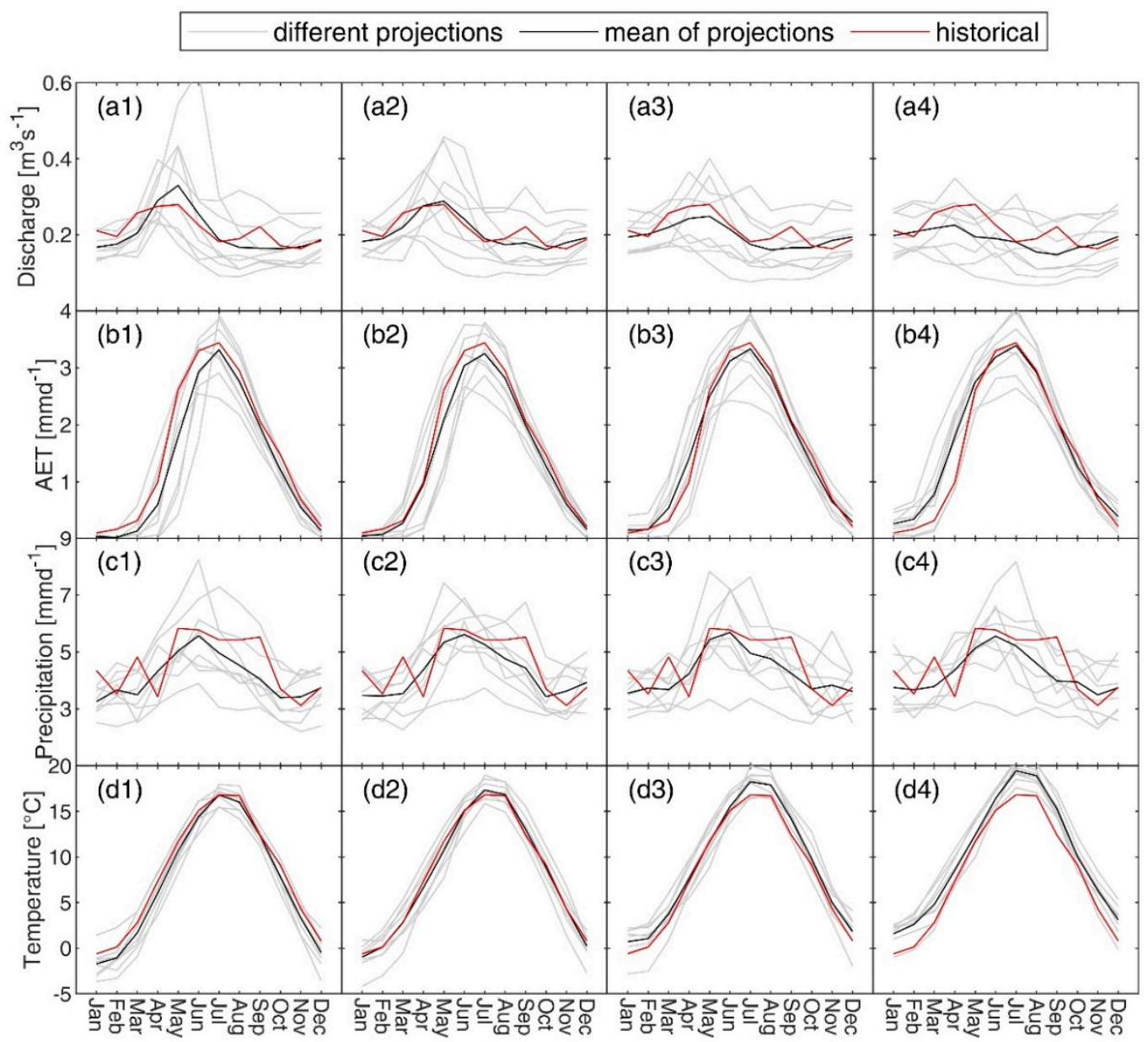

Figure 7. Comparisons between historical and projected mean monthly (a) discharge, (b) actual evapotranspiration, (c) precipitation, and (d) temperature, where the number 1-4 represent the four projected time periods: 2021-2040, 2041-2060, 2061-2080, and 2081-2100, respectively. The red line shows the historical simulations (discharge, AET) or observations (precipitation, temperature) for 1994-2019. The black line indicates the mean of the simulations obtained from the eight climate projections while the grey lines represent the results from the individual climate projections.

\section{Discussion}

Taking wet and dry deposition into account, the $\mathrm{N}$ deposition in the Zöbelboden catchment increased until the year 1980 to $30-35 \mathrm{~kg} \mathrm{~N} \mathrm{ha}^{-1} \mathrm{y}^{-1}$ and thereafter only slowly decreased to the current levels of $25.5 \pm 3.6$ and $19.9 \pm 4.2 \mathrm{~kg} \mathrm{~N} \mathrm{ha}^{-1} \mathrm{y}^{-1}$ in the spruce and the mixed deciduous forests, respectively. Though there is quite some uncertainty regarding the calculation of dry deposition [52], this input of $\mathrm{N}$ was close to or exceeding the critical load (empirical CL at $10-20 \mathrm{~kg} \mathrm{~N} \mathrm{ha}^{-1} \mathrm{y}^{-1}$ according to [53]). In spite of these high inputs, during the last two decades, still $70-83 \%$ of the added DIN was retained in the catchment's vegetation, soils, the epikarst, the vadose or saturated zone. Retention of DIN only decreased during a period of forest stand-replacements in the catchment, which were caused by wind throw and bark beetle infestations at $5-10 \%$ of the area in the years $2007-2010$. We infer from our results that DIN drainage must have increased with the increase in $\mathrm{N}$ deposition prior to the start of monitoring, staying at an elevated level until today. Future DIN discharge will depend upon a number of interacting factors, both potentially increasing or decreasing leaching loss of DIN. 


\subsection{Catchment $N$ Retention}

Several hydrological studies have been carried out to describe the dynamics of the Zöbelboden dolomite karst catchment. Water isotope studies found that the majority of the precipitation reaches the gauging station within a few months (Humer and Kralik, 2008; Kralik et al., 2009), which is in accordance with modeling results $[37,47]$. However, using age dating and artificial tracer experiments at individual springs within the study area, Kralik et al. (2009) also found ages from several days to several decades representing fast and slow flow paths also occurring in the catchment. By modeling DIN discharge, [37] inferred that slower flow paths do not have a significant impact on the retardation capacity of the hydrological system due to their small contribution $(<5 \%)$. Fast flow paths become apparent during rain events and snow melting when $\mathrm{NO}_{3}{ }^{-}$concentrations increase within hours after short dissolution phases. Only during these events, $\mathrm{NO}_{3}{ }^{-}$concentration reaches $>10 \mathrm{mg} \mathrm{L}^{-1}$. High-flow events, therefore, dominate DIN discharge (e.g., 50\% of the annual DIN discharge occurs during the highest $10 \%$ runoff events). We might have underestimated the contribution of these events to DIN discharge with the weekly grab sample data by systematically missing stronger flushing events (see the comparison between the grab sample and high-resolution data below).

Taking the difference between the DIN, which was deposited into the forests and soils, and the measured and modeled [37] DIN discharge, we inferred that approximately $\sim 70-83 \%$ was retained in the catchment during the last two decades. This considerable retention capacity of high amounts of chronic $\mathrm{N}$ deposition is in line with observational and experimental studies. High $\mathrm{N}$ retention capacity $(>80 \%$ ) was found in many unmanaged (mostly forested) catchments in Europe during the period 1990-2012 [19]. Inorganic $N$ retention also stayed relatively high in long-term whole catchment $\mathrm{N}$ addition experiments: $84-96 \%$ in Sweden [54], 1/3 additional leaching compared to a control catchment in Switzerland [38], and $>81 \%$ in Maine, USA [55]. Obviously, only very high N deposition (100 $\left.\mathrm{kg} \mathrm{N} \mathrm{ha}^{-1} \mathrm{y}^{-1}\right)$ causes strong DIN leaching $\left(>10 \mathrm{~kg} \mathrm{~N} \mathrm{ha}^{-1} \mathrm{y}^{-1}\right)$ in forests $[17,56]$.

The $\mathrm{N}$ inputs to the catchment were strongly dominated by DIN and only $11 \%$ (deciduous forest) and $16 \%$ (coniferous forest) of the total $\mathrm{N}$ deposited as DON. Since DON discharge is most often related to DON deposition into forests [57], DON discharge also remained low. On average, 7.5\% of the total $\mathrm{N}$ left the catchment in the form of DON.

Only a part of the deposited $\mathrm{N}$ reached the soil seepage water. When taking the difference between the sum of the annual mean aboveground litterfall of $15 \mathrm{~kg} \mathrm{~N} \mathrm{ha}^{-1} \mathrm{y}^{-1}$ [58] and the annual mean $\mathrm{N}$ deposition in the throughfall of the two dominant forest types, and the nitrate flux from the soils, which was on average $7.9 \mathrm{~kg} \mathrm{~N} \mathrm{ha}^{-1} \mathrm{y}^{-1}$ in a mixed deciduous forest [58] and $11.3 \mathrm{~kg} \mathrm{~N} \mathrm{ha}^{-1} \mathrm{y}^{-1}$ in a spruce forest [13], we found that $66-71 \%$ of the inorganic $\mathrm{N}$ was retained either in the soil or the vegetation. A modeling study [59] estimated that on average $3.4 \mathrm{~kg} \mathrm{~N} \mathrm{ha}^{-1} \mathrm{y}^{-1}$ was lost via gaseous emission in the forms of $\mathrm{N}_{2} \mathrm{O}, \mathrm{N}_{2}$, and $\mathrm{NO}$. Hence, $\mathrm{N}$ retention might have been slightly lower but note that we disregarded belowground litter input. In spite of these uncertainties, it seems safe to state that either the soils or the vegetation were the main sinks of deposited $\mathrm{N}$ and not sinks related to the vadose or saturated zone of the karst catchment. Since soil inventories clearly showed decreasing N stocks (approximately $19 \mathrm{~kg} \mathrm{~N} \mathrm{ha}^{-1} \mathrm{y}^{-1}$ when taking the organic layer and the first $10 \mathrm{~cm}$ of the mineral soil into account), $\mathrm{N}$ immobilization in plant biomass must have been the main $\mathrm{N}$ sink. Leitner et al. [58] calculated an annual tree $\mathrm{N}$ uptake of $61 \mathrm{~kg} \mathrm{~N} \mathrm{ha}^{-1} \mathrm{y}^{-1}$ for the mixed deciduous forests in the catchment. Apart from the general increase in $\mathrm{CO}_{2}$ concentrations in the air, warming occurred particularly since the late 1980s and accumulated to an increase of the mean annual temperature of $1.4{ }^{\circ} \mathrm{C}$ between 1991 and 2019 as compared to the period between 1951 and 1970. All of these factors together with $\mathrm{N}$ fertilization led to an increase in tree growth all over Europe until about 2010 [60] and very likely have facilitated $\mathrm{N}$ uptake in trees in our study area.

In the catchment runoff, we found between $4.4 \mathrm{~kg} \mathrm{~N} \mathrm{ha}^{-1} \mathrm{y}^{-1}$ (measurements between 2000 and 2018) and $5.8 \mathrm{~kg} \mathrm{~N} \mathrm{ha}^{-1} \mathrm{y}^{-1}$ (model-based estimate according to Hartmann et al. [47]). Even though it is difficult to correctly measure both the soil seepage flux and the karst catchment runoff, mixing must have had a significant additional effect on DIN discharge besides the $\mathrm{N}$ immobilization in trees. 
Apart from mixing, the attenuation of DIN in the karst aquifer might come from the use of deepwater of the vadose zone by trees [61] and microbial uptake on biofilms within the saturated zone [62].

\subsection{Long-Term Trends Versus Short Pulses}

Whole ecosystem fertilization experiments showed that an increase in nitrate discharge followed the onset of $\mathrm{N}$ addition from a few years and remained stable thereafter $[31,38]$. The monitoring at Zöbelboden started in the early 1990s when $\mathrm{N}$ deposition was already elevated for many years (in the 1950s $\mathrm{N}$ deposition exceeded $15 \mathrm{~kg} \mathrm{ha}^{-1} \mathrm{y}^{-1}$ ). However, it is safe to assume that DIN leaching increased during these years of increasing $\mathrm{N}$ deposition. Many Austrian forests were and still are $\mathrm{N}$ deficient because of over-utilization in the past $[63,64]$. When focusing on nitrate, because it is by far the dominating $\mathrm{N}$ form in the catchment runoff (only $3 \%$ of DIN discharge was in the form $\mathrm{NH}_{4}{ }^{+}-\mathrm{N}$ ), we did not find a long-term trend in its concentrations nor in its discharge (only $\mathrm{NH}_{4}{ }^{+}-\mathrm{N}$ decreased significantly). However, the wind throw and bark beetle disturbances to the forest caused a strong increase in nitrate concentrations and fluxes for some years. This is a known effect caused by less $\mathrm{N}$ uptake in trees and a surplus of mineralized soil $\mathrm{N}[32,33,65]$, which is subsequently leached to the aquifer. Hartmann et al. [37] estimated that an additional $2.7 \mathrm{~kg} \mathrm{~N} \mathrm{ha}^{-1} \mathrm{y}^{-1}$ leached annually during the disturbance period. Increased mineralization of soil $\mathrm{N}$ and subsequent leaching might be partly responsible for the strong decrease in soil $\mathrm{N}$ stocks.

\subsection{Expected Future Pathways}

The retention of deposited $\mathrm{N}$ in the catchment will depend upon a number of factors. First and foremost, DIN discharge will be regulated by climatic changes as was $\mathrm{N}$ leaching with soil seepage [13]. Soils on carbonate bedrock are often shallow and characterized by high stone content in the mineral soil, hence have a very high infiltration capacity [12]. The climate projections under RCP 8.5 indicates a decrease of $6-10 \%\left(100-166 \mathrm{~mm} \mathrm{y}^{-1}\right)$ in the annual precipitation in the coming 80 years at this study site. There is no vast change in annual mean temperature in the near 40 years, but it will increase by $1.9^{\circ} \mathrm{C}$ till 2100 according to the eight climate projections. The change in climate forcing will affect the hydrological response of the system leading to a decrease of $12 \%$ for the mean annual discharge until the end of this century. The projected mean annual AET shows a decrease in the coming 40 years since a precipitation decrease leads to less available water for evapotranspiration under similar temperature conditions (similar energy limit). However, the model projects an increase of $8 \%\left(48 \mathrm{~mm} \mathrm{y}^{-1}\right)$ in AET in 2080-2100, which may be due to the obvious temperature increase throughout the whole year (Figure 7d4) that elevates the energy availability, particularly in winter and spring. We might expect lower $\mathrm{N}$ export in the catchment runoff but some uncertainty remains because high-flow conditions might increase even with lower average precipitation [66] and more frequent droughts additionally have the potential to increase $\mathrm{NO}_{3}{ }^{-}-\mathrm{N}$ export in the area [58]. Changes in the amount and timing of winter snowfall and the subsequent changes in snowmelt patterns [67] will also affect future DIN leaching as shown in a number of studies [68]. The projected increase of temperatures will most likely lower the duration of snow coverage at the LTER Zöbelboden and may increase the rain and rain-on-snow events in winter with effects on discharge behavior [69]. Moreover, we expect higher fluctuation in soil climate during the winter, which will very likely affect $\mathrm{N}$ mineralization and $\mathrm{N}$ pools [70-72].

Climate might also indirectly elevate $\mathrm{N}$ retention, particularly through increased immobilization in trees due to warming [59]. However, this scenario could be hampered by limited tree growth due to nutrient deficiencies [22,41] and more frequent drought events. Deficiencies were found for some nutrients, particularly for $\mathrm{N}$ in Norway spruce but not so for European beech, and for $\mathrm{P}$ and $\mathrm{K}$ in both tree species. Ratios of $\mathrm{N}$ to other nutrients did not indicate increasing imbalances, which were partly made responsible for the tree growth reduction found in some regions in Europe and the US during recent years $[21,22]$. Although drought events in the past have had negative impacts on tree growth at Zöbelboden [73], precipitation is generally high and expected future decreases will unlikely 
be dramatic according to the simulations. However, water holding capacity is low in the shallow and stony soils, promoting water limitation for tree growth albeit relatively high precipitation [74]. Additionally, tree growth predominately occurs until the end of June so that lower soil moisture during spring due to changes in the snow cover and snow melting patterns may be particularly important [75]. Future effects of drought on tree growth and $\mathrm{N}$ cycling are therefore highly uncertain and a matter of current research in the study area.

We do not expect $\mathrm{N}$ oligotrophication in the near future, which occurred in the northern hardwood forests in the US due to a complex interplay of factors controlling forest production [20], simply because the currently legislated $\mathrm{N}$ emission reductions will only cause a slight decrease in the chronically high $\mathrm{N}$ deposition in the study area (in the range of $\sim 2-3 \mathrm{~kg} \mathrm{~N} \mathrm{ha}^{-1} \mathrm{y}^{-1}$ in the year 2030 as compared to 2015 according to [8]).

The soils at Zöbelboden have top-soil C:N ratios $<20$ [76], where microbial immobilization of added $\mathrm{N}$ may be low [17]. The high amount of deposition in the form of $\mathrm{NH}_{4}{ }^{+}$may also suppress microbial $\mathrm{NO}_{3}{ }^{-}$immobilization [77]. However, Brumme and Khanna [78] exemplified that soils on carbonate bedrock with high carbon contents and high $\mathrm{pH}$ values tend to retain large amounts of $\mathrm{N}$. A large share of the high $\mathrm{N}$ leaching rates in the seepage water are likely directly from deposited $\mathrm{NO}_{3}{ }^{-}$, due to coarse-textured, shallow soils and preferential flow paths [12,13] rather than mineralized $\mathrm{NO}_{3}{ }^{-}$from the soil matrix. In a yet unpublished $\mathrm{N}$ addition experiment carried out in the study area, we found an increase in soil organic matter storage in the treatment plots as a result of reduced gross $\mathrm{N}$ mineralization rates and enzyme activity, which is in line with the findings from many other studies $[27,28]$. However, SOM increase only occurred in the organic layer and not in the mineral soil. Moreover, our soil inventory data showed that $\mathrm{N}$ stocks solely increased in the $\mathrm{O}$ horizon. Continued deposition of $\mathrm{N}$ in the current range will hence unlikely cause any major change in $\mathrm{NO}_{3}{ }^{-}$leaching.

Pulses of elevated $\mathrm{NO}_{3}{ }^{-}$runoff over some years have to be expected in the future as a consequence of climatically triggered forest disturbances. The abundance of Norway spruce has been artificially elevated in the study area as in all of Austria. With its vulnerability to a combination of disturbance agents, i.e., storms, drought, and spruce bark beetle [79], stand-replacing disturbances will occur more likely until deciduous trees have become more dominant [80].

\section{Conclusions}

By using the conceptual model of [17], the Zöbelboden catchment is experiencing kinetic N saturation, where soil and vegetation still immobilize $\mathrm{N}$ but the rate of $\mathrm{N}$ input exceeds their sink capacity. Thereby, $\mathrm{N}$ retention and leaching loss occur at the same time with elevated but stable DIN discharge and pulses of nitrate runoff during years with stand-replacing disturbances. Our data do not suggest any major change in the $\mathrm{N}$ retention in the near future. However, it also shows that discharge from unmanaged forests in upstream areas exposed to long-term, high $\mathrm{N}$ deposition can contribute to elevated nitrate concentrations of drinking water resources. Particular attention should be paid to forest management in order to reduce the risk of stand-replacing disturbances, because inorganic $\mathrm{N}$ deposition, which is usually retained, leaves the system during such periods via catchment runoff.

Author Contributions: Conceptualization, T.D., M.K., A.H., and M.M.; methodology, T.D. and Y.L.; software, A.H. and Y.L.; formal analysis, T.D., S.G., and Y.L.; data curation, I.D., H.B., G.P., S.G. and J.K.; writing-original draft preparation, T.D.; writing-review and editing, H.B., I.D., S.G., F.H., J.K., M.K., G.P., A.H., and Y.L.; visualization, T.D., S.G.; funding acquisition, T.D. and M.M. All authors have read and agreed to the published version of the manuscript.

Funding: H.B., I.D., T.D., J.K., S.G., G.P., and some measuring equipment were supported through LTER-CWN (FFG, F\&E Infrastrukturförderung, project number 858024). T.D. and S.G. were also funded through the European Horizon 2020 Project eLTER-PLUS (INFRAIA-01-2018-2019). A.H. and Y.L. were supported by the Emmy-Noether-Programme of the German Research Foundation (DFG, grant number: HA 8113/1-1; project "Global Assessment of Water Stress in Karst Regions in a Changing World"). 
Acknowledgments: Long-term monitoring was over the years financed by several Austrian Federal Ministries through theircontribution to the UNECE-CLRTAP Integrated Monitoring Program. We acknowledge financial, technical, and laboratory support from the Kalkalpen National Park and the Austrian Federal Forests (ÖBf).

Conflicts of Interest: The authors declare no conflict of interest.

\section{References}

1. Bobbink, R.; Hicks, K.; Galloway, J.; Spranger, T.; Alkemade, R.; Ashmore, M.; Bustamante, M.; Cinderby, S.; Davidson, E.; Dentener, F.; et al. Global assessment of nitrogen deposition effects on terrestrial plant diversity: A synthesis. Ecol. Appl. 2010, 20, 30-59. [CrossRef] [PubMed]

2. de Vries, W.; Du, E.; Butterbach-Bahl, K. Short and long-term impacts of nitrogen deposition on carbon sequestration by forest ecosystems. Curr. Opin. Environ. Sustain. 2014, 9, 90-104. [CrossRef]

3. Gruber, N.; Galloway, J.N. An Earth-system perspective of the global nitrogen cycle. Nature 2008, 451, $293-296$. [CrossRef] [PubMed]

4. Yue, K.; Peng, Y.; Peng, C.; Yang, W.; Peng, X.; Wu, F. Stimulation of terrestrial ecosystem carbon storage by nitrogen addition: A meta-analysis. Sci. Rep. 2016, 6, 19895. [CrossRef]

5. Vet, R.; Artz, R.S.; Carou, S.; Shaw, M.; Ro, C.-U.; Aas, W.; Baker, A.; van Bowersox, C.; Dentener, F.; Galy-Lacaux, C.; et al. A global assessment of precipitation chemistry and deposition of sulfur, nitrogen, sea salt, base cations, organic acids, acidity and $\mathrm{pH}$, and phosphorus. Atmos. Environ. 2014, 93, 3-100. [CrossRef]

6. EMEP. Transboundary Particulate Matter, Photo-Oxidants, Acidifying and Eutrophying Components; EMEP Status Report; EMEP(MSC-W of EMEP): Oslo, Norway, 2017.

7. Schmitz, A.; Sanders, T.; Bolte, A.; Bussotti, F.; Dirnböck, T.; Johnson, J.; Penuelas, J.; Pollastrini, M.; Prescher, A.-K.; Sardans, J.; et al. Responses of forest ecosystems in Europe to decreasing nitrogen deposition. Environ. Pollut. 2019, 244, 980-994. [CrossRef]

8. Dirnböck, T.; Pröll, G.; Austnes, K.; Beloica, J.; Beudert, B.; Canullo, R.; de Marco, A.; Fornasier, M.F.; Futter, M.; Georgen, K.; et al. Currently legislated decreases in nitrogen deposition will yield only limited plant species recovery in European forests. Environ. Res. Lett. 2018, 13, 125010. [CrossRef]

9. Amann, M.; Anderl, M.; Borken-Kleefeld, J.; Cofala, J.; Heyes, C.; Höglund-Isaksson, L.; Kiesewetter, G.; Klimont, Z.; Moosmann, L.; Rafaj, P.; et al. Progress towards the Achievement of the EU's Air Quality and Emissions Objectives; IIASA: Laxenburg, Austria, 2018.

10. COST. COST 65: Hydrogeological Aspects of Groundwater Protection in Karstic Areas-Final Report. EUROPEAN COMMISSION Directorate-General XII Science, Research and Development Environment Research Programme; European Commission: Luxenbourg, 1995; p. 446.

11. Ford, D.; Wiliams, P. Karst Hydrology and Geomorphology; Wiley: New York, NY, USA, 2007.

12. Jandl, R.; Smidt, S.; Schindlbacher, A.; Englisch, M.; Zechmeister-Boltenstern, S.; Mikovits, C.; Schöftner, P.; Strebl, F.; Fuchs, G. The carbon and nitrogen biogeochemistry of a montane Norway spruce (Picea abies (L.) Karst.) forest: A synthesis of long-term research. Plant Ecol. Divers. 2012, 5, 105-114. [CrossRef]

13. Jost, G.; Dirnböck, T.; Grabner, M.-T.; Mirtl, M. Nitrogen Leaching of Two Forest Ecosystems in a Karst Watershed. Water Air AMP Soil Pollut. 2011, 218, 633-649. [CrossRef]

14. Grimvall, A.; Stålnacke, P.; Tonderski, A. Time scales of nutrient losses from land to sea-A European perspective. Ecol. Eng. 2000, 14, 363-371. [CrossRef]

15. Sutton, M.A.; Howard, C.M.; Erisman, J.W.; Billen, G.; Bleeker, A.; Grennfelt, P.; van Grinsven, H.; Grizzetti, B. (Eds.) The European Nitrogen Assessment; Cambridge University Press: Cambridge, UK, 2011.

16. Aber, J.; McDowell, W.; Nadelhoffer, K.; Magill, A.; Berntson, G.; Kamakea, M.; McNulty, S.; Currie, W.; Rustad, L.; Fernandez, I. Nitrogen saturation in temperate forest ecosystems: Hypotheses revisited. BioScience 1998, 48, 921-934. [CrossRef]

17. Lovett, G.M.; Goodale, C.L. A new conceptual model of nitrogen saturation based on experimental Nitrogen addition to an oak forest. Ecosystems 2011, 14, 615-631. [CrossRef]

18. Vuorenmaa, J.; Augustaitis, A.; Beudert, B.; Bochenek, W.; Clarke, N.; de Wit, H.A.; Dirnböck, T.; Frey, J.; Hakola, H.; Kleemola, S.; et al. Long-term changes (1990-2015) in the atmospheric deposition and runoff water chemistry of sulphate, inorganic nitrogen and acidity for forested catchments in Europe in relation to changes in emissions and hydrometeorological conditions. Sci. Total Environ. 2018, 625, 1129-1145. [CrossRef] [PubMed] 
19. Vuorenmaa, J.; Augustaitis, A.; Beudert, B.; Clarke, N.; de Wit, H.A.; Dirnböck, T.; Frey, J.; Forsius, M.; Indriksone, I.; Kleemola, S.; et al. Long-term sulphate and inorganic nitrogen mass balance budgets in European ICP Integrated Monitoring catchments (1990-2012). Ecol. Indic. 2017, 76, 15-29. [CrossRef]

20. Groffman, P.M.; Driscoll, C.T.; Durán, J.; Campbell, J.L.; Christenson, L.M.; Fahey, T.J.; Fisk, M.C.; Fuss, C.; Likens, G.E.; Lovett, G.; et al. Nitrogen oligotrophication in northern hardwood forests. Biogeochemistry 2018, 141, 523-539. [CrossRef]

21. Horn, K.J.; Thomas, R.Q.; Clark, C.M.; Pardo, L.H.; Fenn, M.E.; Lawrence, G.B.; Perakis, S.S.; Smithwick, E.A.H.; Baldwin, D.; Braun, S.; et al. Growth and survival relationships of 71 tree species with nitrogen and sulfur deposition across the conterminous U.S. PLOS ONE 2018, 13, e0205296. [CrossRef] [PubMed]

22. Braun, S.; Schindler, C.; Rihm, B. Growth trends of beech and Norway spruce in Switzerland: The role of nitrogen deposition, ozone, mineral nutrition and climate. Sci. Total Environ. 2017, 599-600, 637-646. [CrossRef]

23. Solberg, S.; Dobbertin, M.; Reinds, G.J.; Lange, H.; Andreassen, K.; Fernandez, P.G.; Hildingsson, A.; de Vries, W. Analyses of the impact of changes in atmospheric deposition and climate on forest growth in European monitoring plots: A stand growth approach. For. Ecol. Manag. 2009, 258, 1735-1750. [CrossRef]

24. Lilleskov, E.A.; Kuyper, T.W.; Bidartondo, M.I.; Hobbie, E.A. Atmospheric nitrogen deposition impacts on the structure and function of forest mycorrhizal communities: A review. Environ. Pollut. 2019, 246, 148-162. [CrossRef]

25. van der Linde, S.; Suz, L.M.; Orme, C.D.L.; Cox, F.; Andreae, H.; Asi, E.; Atkinson, B.; Benham, S.; Carroll, C.; Cools, N.; et al. Environment and host as large-scale controls of ectomycorrhizal fungi. Nature 2018. [CrossRef]

26. Templer, P.H.; Mack, M.C.; Iii, F.S.C.; Christenson, L.M.; Compton, J.E.; Crook, H.D.; Currie, W.S.; Curtis, C.J.; Dail, D.B.; D'Antonio, C.M.; et al. Sinks for nitrogen inputs in terrestrial ecosystems: A meta-analysis of $15 \mathrm{~N}$ tracer field studies. Ecology 2012, 93, 1816-1829. [CrossRef] [PubMed]

27. Janssens, I.A.; Dieleman, W.; Luyssaert, S.; Subke, J.A.; Reichstein, M.; Ceulemans, R.; Ciais, P.; Dolman, A.J.; Grace, J.; Matteucci, G.; et al. Reduction of forest soil respiration in response to nitrogen deposition. Nat. Geosci. 2010, 3, 315-322. [CrossRef]

28. Forstner, S.J.; Wechselberger, V.; Müller, S.; Keibinger, K.M.; Díaz-Pinés, E.; Wanek, W.; Scheppi, P.; Hagedorn, F.; Gundersen, P.; Tatzber, M.; et al. Vertical Redistribution of Soil Organic Carbon Pools After Twenty Years of Nitrogen Addition in Two Temperate Coniferous Forests. Ecosystems 2019, 22, 379-400. [CrossRef] [PubMed]

29. Dise, N.B.; Wright, R.F. Nitrogen leaching from European forests in relation to nitrogen deposition. For. Ecol. Manag. 1995, 71, 153-161. [CrossRef]

30. MacDonald, J.A.; Dise, N.B.; Matzner, E.; Armbruster, M.; Gundersen, P.; Forsius, M. Nitrogen input together with ecosystem nitrogen enrichment predict nitrate leaching from European forests. Glob. Chang. Biol. 2002, 8, 1028-1033. [CrossRef]

31. Moldan, F.; Hruška, J.; Evans, C.; Hauhs, M. Experimental simulation of the effects of extreme climatic events on major ions, acidity and dissolved organic carbon leaching from a forested catchment, Gårdsjön, Sweden. Biogeochemistry 2011, 107, 455-469. [CrossRef]

32. Huber, C. Long Lasting Nitrate Leaching after Bark Beetle Attack in the Highlands of the Bavarian Forest National Park. J. Environ. Qual. 2005, 34, 1772-1779. [CrossRef]

33. Kohlpaintner, M.; Huber, C.; Weis, W.; Göttlein, A. Spatial and temporal variability of nitrate concentration in seepage water under a mature Norway spruce [Picea abies (L.) Karst] stand before and after clear cut. Plant Soil 2010, 314, 285-301. [CrossRef]

34. Rothe, A.; Mellert, K. Effects of Forest Management on Nitrate Concentrations in Seepage Water of Forests in Southern Bavaria, Germany. Water Air Soil Pollut 2004, 156, 337-355. [CrossRef]

35. Bernal, S.; Hedin, L.O.; Likens, G.E.; Gerber, S.; Buso, D.C. Complex response of the forest nitrogen cycle to climate change. Proc. Natl. Acad. Sci. USA 2012, 109, 3406-3411. [CrossRef]

36. Aber, J.D.; Ollinger, S.V.; Driscoll, C.T.; Likens, G.E.; Holmes, R.T.; Freuder, R.J.; Goodale, C.L. Inorganic nitrogen losses from a forested ecosystem in response to physical, chemical, biotic, and climatic perturbations. Ecosystems 2002, 5, 648-658. [CrossRef] 
37. Hartmann, A.; Kobler, J.; Kralik, M.; Dirnböck, T.; Humer, F.; Weiler, M. Model-aided quantification of dissolved carbon and nitrogen release after windthrow disturbance in an Austrian karst system. Biogeosciences 2016, 13, 159-174. [CrossRef]

38. Schleppi, P.; Curtaz, F.; Krause, K. Nitrate leaching from a sub-alpine coniferous forest subjected to experimentally increased $\mathrm{N}$ deposition for 20 years, and effects of tree girdling and felling. Biogeochemistry 2017, 134, 319-335. [CrossRef]

39. Senf, C.; Pflugmacher, D.; Zhiqiang, Y.; Sebald, J.; Knorn, J.; Neumann, M.; Hostert, P.; Seidl, R. Canopy mortality has doubled in Europe's temperate forests over the last three decades. Nat. Commun. 2018, 9, 4978. [CrossRef] [PubMed]

40. Schelhaas, M.J.; Nabuurs, G.J.; Schuck, A. Natural disturbances in the European forests in the 19th and 20th centuries. Glob. Chang. Biol. 2003, 9, 1620-1633. [CrossRef]

41. Jonard, M.; Fürst, A.; Verstraeten, A.; Thimonier, A.; Timmermann, V.; Potočić, N.; Waldner, P.; Benham, S.; Hansen, K.; Merilä, P.; et al. Tree mineral nutrition is deteriorating in Europe. Glob. Chang. Biol. 2015, 21, 418-430. [CrossRef]

42. Staelens, J.; Houle, D.; de Schrijver, A.; Neirynck, J.; Verheyen, K. Calculating Dry Deposition and Canopy Exchange with the Canopy Budget Model: Review of Assumptions and Application to Two Deciduous Forests. Water Air Soil Pollut. 2008, 191, 149-169. [CrossRef]

43. Schöpp, W.; Posch, M.; Mylona, S.; Johansson, M. Long-term development of acid deposition (1880-2030) in sensitive freshwater regions in Europe. Hydrol. Earth Syst. Sci. 2003, 7, 436-446. [CrossRef]

44. Mellert, K.H.; Göttlein, A. Comparison of new foliar nutrient thresholds derived from van den Burg's literature compilation with established central European references. Eur. J. For. Res. 2012, 131, 1461-1472. [CrossRef]

45. Kralik, M.; Humer, F.; Papesch, W.; Tesch, R.; Suckow, A.; Han, L.F. (Eds.) Karstwater-Ages in an Alpine Dolomite Catchment, Austria: Delta-18O, 3H,3H/3He, CFC and Dye Tracer Investigations; EGU General Assembly: Vienna, Austria, 2009.

46. Hartmann, A.; Kralik, M.; Humer, F.; Lange, J.; Weiler, M. Identification of a karst system's intrinsic hydrodynamic parameters: Upscaling from single springs to the whole aquifer. Environ. Earth Sci. 2011, 65, 2377-2389. [CrossRef]

47. Hartmann, A.; Weiler, M.; Wagener, T.; Lange, J.; Kralik, M.; Humer, F.; Mizyed, N.; Rimmer, A.; Barberá, J.A.; Andreo, B.; et al. Process-based karst modelling to relate hydrodynamic and hydrochemical characteristics to system properties. Hydrol. Earth Syst. Sci. 2013, 17, 3305-3321. [CrossRef]

48. Hartmann, A.; Mudarra, M.; Andreo, B.; Marín, A.; Wagener, T.; Lange, J. Modeling spatiotemporal impacts of hydroclimatic extremes on groundwater recharge at a Mediterranean karst aquifer. Water Resour. Res. 2014, 50, 6507-6521. [CrossRef]

49. Giorgi, F.; Jones, C.; Asrar, G.R. Addressing climate information needs at the regional level: The CORDEX framework. Bull. World Meteorol. Organ. 2009, 58, 175-183.

50. Gutowski, W.J., Jr.; Giorgi, F.; Timbal, B.; Frigon, A.; Jacob, D.; Kang, H.-S.; Raghavan, K.; Lee, B.; Lennard, C.; Nikulin, G.; et al. WCRP COordinated Regional Downscaling EXperiment (CORDEX): A diagnostic MIP for CMIP6. Geosci. Model Dev. 2016, 9, 4087-4095. [CrossRef]

51. Cinquini, L.; Crichton, D.; Mattmann, C.; Harney, J.; Shipman, G.; Wang, F.; Ananthakrishnan, R.; Miller, N.; Denvil, S.; Morgan, M.; et al. The Earth System Grid Federation: An open infrastructure for access to distributed geospatial data. Future Gener. Comput. Syst. 2014, 36, 400-417. [CrossRef]

52. Adriaenssens, S.; Staelens, J.; Baeten, L.; Verstraeten, A.; Boeckx, P.; Samson, R.; Verheyen, K. Influence of canopy budget model approaches on atmospheric deposition estimates to forests. Biogeochemistry 2013, 116, 215-229. [CrossRef]

53. Bobbink, R.; Hettelingh, J.P. Review and Revision of Empirical Critical Loads and Dose-Response Relationships: Proceedings of the Expert Workshop, Noordwijkerhout 23-24 June 2010; RIVM: Bilthoven, The Netherlands, 2011.

54. Moldan, F.; Jutterström, S.E.A.K.; Hruška, J.; Wright, R.F. Experimental addition of nitrogen to a whole forest ecosystem at Gårdsjön, Sweden (NITREX): Nitrate leaching during 26 years of treatment. Environ. Pollut. 2018, 242, 367-374. [CrossRef]

55. Patel, K.F.; Fernandez, I.J.; Nelson, S.J.; Gruselle, M.-C.; Norton, S.A.; Weiskittel, A.R. Forest N Dynamics after 25 years of Whole Watershed N Enrichment: The Bear Brook Watershed in Maine. Soil Sci. Soc. Am. J. 2019, 83, S161-S174. [CrossRef] 
56. Magill, A.H.; Aber, J.D.; Currie, W.S.; Nadelhoffer, K.J.; Martin, M.E.; McDowell, W.H.; Melillo, J.M.; Steudler, P. Ecosystem response to 15 years of chronic nitrogen additions at the Harvard Forest LTER, Massachusetts, USA. For. Ecol. Manag. 2004, 196, 7-28. [CrossRef]

57. Michalzik, B.; Kalbitz, K.; Park, J.H.; Solinger, S.; Matzner, E. Fluxes and concentrations of dissolved organic carbon and nitrogen-A synthesis for temperate forests. Biogeochemistry 2001, 52, 173-205. [CrossRef]

58. Leitner, S.; Dirnböck, T.; Kobler, J.; Zechmeister-Boltenstern, S. Legacy effects of drought on nitrate leaching in a temperate mixed forest on karst. J. Environ. Manag. 2020, 262. [CrossRef] [PubMed]

59. Dirnböck, T.; Foldal, C.; Djukic, I.; Kobler, J.; Haas, E.; Kiese, R.; Kitzler, B. Historic nitrogen deposition determines future climate change effects on nitrogen retention in temperate forests. Clim. Chang. 2017, 1, 15. [CrossRef]

60. Pretzsch, H.; Biber, P.; Schütze, G.; Uhl, E.; Rötzer, T. Forest stand growth dynamics in Central Europe have accelerated since 1870. Nat. Commun. 2014, 5. [CrossRef]

61. Carrière, S.D.; Martin-StPaul, N.K.; Cakpo, C.B.; Patris, N.; Gillon, M.; Chalikakis, K.; Doussan, C.; Olioso, A.; Babic, M.; Jouineau, A.; et al. The role of deep vadose zone water in tree transpiration during drought periods in karst settings-Insights from isotopic tracing and leaf water potential. Sci. Total Environ. 2020, 699, 134332. [CrossRef]

62. Wilhartitz, I.C.; Kirschner, A.K.T.; Stadler, H.; Herndl, G.J.; Dietzel, M.; Latal, C.; Mach, R.L.; Farnleitner, A.H. Heterotrophic prokaryotic production in ultraoligotrophic alpine karst aquifers and ecological implications. FEMS Microbiol. Ecol. 2009, 68, 287-299. [CrossRef]

63. Jandl, R.; Smidt, S.; Mutsch, F.; Fürst, A.; Zechmeister, H.; Bauer, H.; Dirnböck, T. Acidification and Nitrogen Eutrophication of Austrian Forest Soils. Appl. Environ. Soil Sci. 2012, 2012, 9. [CrossRef]

64. Glatzel, G. The nitrogen status of Austrian forest ecosystems as influenced by atmospheric deposition, biomass harvesting and lateral organomass exchange. Plant Soil 1990, 128, 67-74. [CrossRef]

65. Dirnböck, T.; Kobler, J.; Kraus, D.; Grote, R.; Kiese, R. Impacts of management and climate change on nitrate leaching in a forested karst area. J. Environ. Manag. 2016, 165, 243-252. [CrossRef]

66. Yin, J.; Gentine, P.; Zhou, S.; Sullivan, S.C.; Wang, R.; Zhang, Y.; Guo, S. Large increase in global storm runoff extremes driven by climate and anthropogenic changes. Nat. Commun. 2018, 9, 4389. [CrossRef]

67. Barnett, T.P.; Adam, J.C.; Lettenmaier, D.P. Potential impacts of a warming climate on water availability in snow-dominated regions. Nature 2005, 438, 303-309. [CrossRef]

68. Crossman, J.; Catherine Eimers, M.; Casson, N.J.; Burns, D.A.; Campbell, J.L.; Likens, G.E.; Mitchell, M.J.; Nelson, S.J.; Shanley, J.B.; Watmough, S.A.; et al. Regional meteorological drivers and long term trends of winter-spring nitrate dynamics across watersheds in northeastern North America. Biogeochemistry 2016, 130, 247-265. [CrossRef]

69. Casson, N.J.; Eimers, M.C.; Buttle, J.M. The contribution of rain-on-snow events to nitrate export in the forested landscape of south-central Ontario, Canada. Hydrol. Process. 2010, 24, 1985-1993. [CrossRef]

70. Durán, J.; Morse, J.L.; Groffman, P.M.; Campbell, J.L.; Christenson, L.M.; Driscoll, C.T.; Fahey, T.J.; Fisk, M.C.; Likens, G.E.; Melillo, J.M.; et al. Climate change decreases nitrogen pools and mineralization rates in northern hardwood forests. Ecosphere 2016, 7, 53. [CrossRef]

71. Li, W.; Wu, J.; Bai, E.; Guan, D.; Wang, A.; Yuan, F.; Wang, S.; Jin, C. Response of terrestrial nitrogen dynamics to snow cover change: A meta-analysis of experimental manipulation. Soil Biol. Biochem. 2016, 100, 51-58. [CrossRef]

72. Schütt, M.; Borken, W.; Stange, C.F.; Matzner, E. Substantial net N mineralization during the dormant season in temperate forest soils. J. Plant Nutr. Soil Sci. 2014, 177, 566-572. [CrossRef]

73. Hartl-Meier, C.; Zang, C.; Büntgen, U.; Esper, J.; Rothe, A.; Göttlein, A.; Dirnböck, T.; Treydte, K. Uniform climate sensitivity in tree-ring stable isotopes across species and sites in a mid-latitude temperate forest. Tree Physiol. 2014, 35, 4-15. [CrossRef]

74. Kobler, J.; Jandl, R.; Dirnböck, T.; Mirtl, M.; Schindlbacher, A. Effects of stand patchiness due to windthrow and bark beetle abatement measures on soil $\mathrm{CO}_{2}$ efflux and net ecosystem productivity of a managed temperate mountain forest. Eur. J. For. Res. 2015, 134, 683-692. [CrossRef]

75. Blankinship, J.C.; Meadows, M.W.; Lucas, R.G.; Hart, S.C. Snowmelt timing alters shallow but not deep soil moisture in the Sierra Nevada. Water Resour. Res. 2014, 50, 1448-1456. [CrossRef] 
76. Pröll, G.; Dullinger, S.; Dirnböck, T.; Kaiser, B.; Richter, A. Effects of nitrogen on tree recruitment in a temperate montane forest as analysed by measured variables and Ellenberg indicator values. Preslia 2011, 83, 111-127.

77. Emmett, B.A. Nitrogen Saturation of Terrestrial Ecosystems: Some Recent Findings and Their Implications for Our Conceptual Framework. Water Air Soil Pollut. Focus 2007, 7, 99-109. [CrossRef]

78. Brumme, R.; Khanna, P.K. Ecological and site historical aspects of $\mathrm{N}$ dynamics and current $\mathrm{N}$ status in temperate forests. Glob. Chang. Biol. 2008, 14, 125-141. [CrossRef]

79. Jandl, R. Climate-induced challenges of Norway spruce in Northern Austria. Trees For. People 2020, 1, 100008. [CrossRef]

80. Thom, D.; Rammer, W.; Seidl, R. The impact of future forest dynamics on climate: Interactive effects of changing vegetation and disturbance regimes. Ecol. Monogr. 2017, 87, 665-684. [CrossRef] [PubMed]

Publisher's Note: MDPI stays neutral with regard to jurisdictional claims in published maps and institutional affiliations.

(C) 2020 by the authors. Licensee MDPI, Basel, Switzerland. This article is an open access article distributed under the terms and conditions of the Creative Commons Attribution (CC BY) license (http://creativecommons.org/licenses/by/4.0/). 